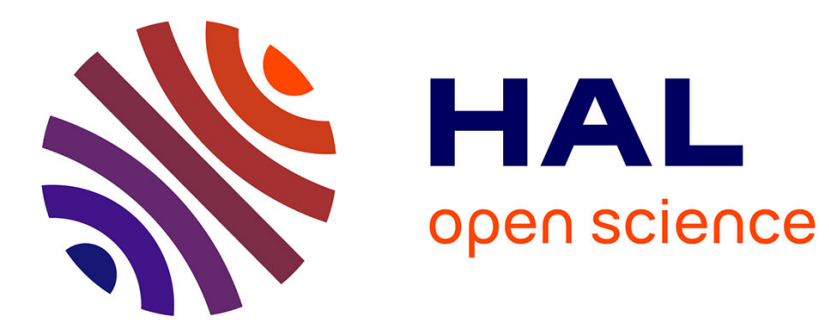

\title{
Competition and risk in the South East Asian commercial banking
}

Hong Liu, Philip Molyneux, Linh H Nguyen

\section{To cite this version:}

Hong Liu, Philip Molyneux, Linh H Nguyen. Competition and risk in the South East Asian commercial banking. Applied Economics, 2011, 10.1080/00036846.2011.579066 . hal-00711456

\section{HAL Id: hal-00711456 \\ https://hal.science/hal-00711456}

Submitted on 25 Jun 2012

HAL is a multi-disciplinary open access archive for the deposit and dissemination of scientific research documents, whether they are published or not. The documents may come from teaching and research institutions in France or abroad, or from public or private research centers.
L'archive ouverte pluridisciplinaire HAL, est destinée au dépôt et à la diffusion de documents scientifiques de niveau recherche, publiés ou non, émanant des établissements d'enseignement et de recherche français ou étrangers, des laboratoires publics ou privés. 


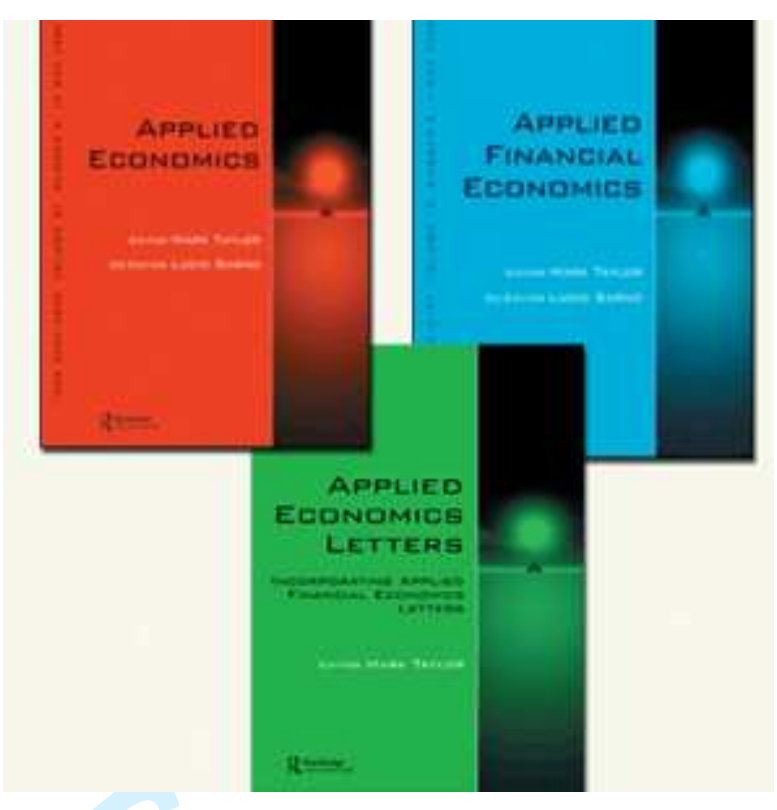

\section{Competition and risk in the South East Asian commercial banking}

\begin{tabular}{|c|c|}
\hline Journal: & Applied Economics \\
\hline Manuscript ID: & APE-2009-0682.R1 \\
\hline Journal Selection: & Applied Economics \\
\hline $\begin{array}{r}\text { Date Submitted by the } \\
\text { Author: }\end{array}$ & 24-Sep-2010 \\
\hline Complete List of Authors: & $\begin{array}{l}\text { Liu, Hong; University of Glasgow, Glasgow Business SChool } \\
\text { Molyneux, Philip; Bangor University, Bangor, Business School } \\
\text { Nguyen, Linh; Saigon Bank for Industry and Trade }\end{array}$ \\
\hline JEL Code: & $\begin{array}{l}\text { G21 - Banks|Other Depository Institutions|Mortgages < G2 - } \\
\text { Financial Institutions and Services < G - Financial Economics, F30 - } \\
\text { General < F3 - International Finance < F - International Economics, } \\
\text { G38 - Government Policy and Regulation < G3 - Corporate Finance } \\
\text { and Governance < G - Financial Economics }\end{array}$ \\
\hline Keywords: & Banking, Competition, Financial Stability, Regulation \\
\hline
\end{tabular}

\section{SCHOLARONE \\ Manuscripts}




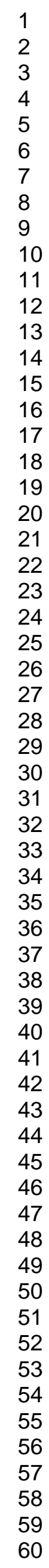

14

15

16

18

19

20

22

24

26

27

29

30

32

33

34

35

36

37

38

39

40

42

43

44

46

47

48

49

50

52

53

54

55

57

58

59

60

Editorial Office, Dept of Economics, Warwick University, Coventry CV4 7AL, UK 


\title{
Competition and risk in the South East Asian commercial banking
}

\author{
Hong Liu ${ }^{a}$, Philip Molyneux ${ }^{\mathrm{b},{ }^{*}, \text { Linh H Nguyen }}{ }^{\mathrm{c}}$ \\ ${ }^{a}$ Glasgow Business School, University of Glasgow, Glasgow, G12 8QQ, UK \\ ${ }^{\mathrm{b}}$ Bangor Business School, Bangor University, Bangor, Gwynedd, LL57 2DG, UK \\ c Saigon Bank for Industry and Trade, 2C Pho Duc Chinh, District 1, Hochiminh City, Vietnam
}

\begin{abstract}
This paper investigates the effects of competition on bank risk-taking behaviour in four South East Asian countries (Indonesia, Malaysia, Philippines and Vietnam). Our main finding is that competition does not increase bank risk-taking behaviour and the results appear robust to different model specifications, estimation approaches and variable construction. We also find that concentration is inversely related to bank risk whereas regulatory restrictions positively influence bank risk-taking.
\end{abstract}

JEL Classification Numbers: G21, F30, L89, G38

Keywords: Bank Competition, Banking System Fragility, Financial Stability, Regulation

\footnotetext{
* Corresponding author. Tel.: +44-1248-382170; fax: +44-1248-364760.

E-mail address: p.molyneux@bangor.ac.uk (P. Molyneux)
} 


\section{Introduction}

One of the major objectives of liberalizing financial sectors in South East Asia is to foster competition. However, after nearly a decade of liberalization programmes aimed at encouraging foreign bank entry, consolidation and other structural reforms, there remains a paucity of information as to whether the changing competitive environment has induced more risky behaviour by banks in the region ${ }^{1}$. An exception is Laeven (2006) who finds that the competitive banking systems of Hong Kong and Singapore are relatively stable, whereas Indonesia 'embeds a lot of risk and is not very competitive' (p.21) ${ }^{2}$. In contrast, the recent literature on the causes of the credit crunch highlight deregulation and excessive competition as factors that have led to financial sector meltdown in the US and elsewhere (see Llewellyn, 2007; Brunnermeier, 2009; Milne, 2009; G30, 2009)

The empirical evidence from outside Asia also provides no clear guide as to whether competition increases or decreases banking sector risk. For example, Dick (2006), Carletti and Hartmann (2003), Demsetz et al. (1996), Keeley (1990), Marcus (1984) and Rhoades and Rutz (1982), all find that under competitive pressures banks tend to foster risk-taking behaviour. This implies that competition damages financial stability. In contrast, others such as Koetter and Poghosyan (2009), Boyd et al. (2006), De Nicolo and Loukoianova (2006), Schaeck et al. (2006), De Nicolo (2000) and Jayaratne and Strahan (1998) find that in more competitive banking markets, the probability of failure is lower, suggesting that competition helps to enhance financial stability.

This paper aims to contribute to the competition-stability/fragility debate by investigating the relationship between competition and bank risk in four South East Asian banking systems between 1998 and 2004. The structure of the paper is as follows. Section 2 discusses the competition-risk relationship in banking and outlines approaches to measuring competition. Section 3 covers the methodology. First, we describe the Panzar and Rosse (1987) $\mathrm{H}$-statistic and outline various approaches to derive this non-structural measure of competition. Following on, we introduce various bank risk measures - loan-loss reserves, loan-loss provisions, profits volatility and the Z-index. The remainder of the methodology section outlines the modelling approach used to link risk and competition. Section 4 reports the data and results and Section 5 is the conclusion.

\section{Does competition induce risk-taking behaviour?}

\footnotetext{
${ }^{1}$ See Ghosh (2006) for an excellent exposition of financial restructuring trends in East Asian financial systems, especially Chapters 1 to 4.

${ }^{2}$ Laeven (2006) also notes that in some banking systems of East Asia have competition levels below pre 199798 crisis levels.
} 
Competition is believed to act as a strong fillip to boost efficiency and lower asymmetric information, which help banks respond better to risks. Therefore, increased banking sector competition is likely to lead to a more stable banking system. However, competition has been claimed to force bank managers to adopt more risky activities in order to compensate for profits erosion originating from offering competitive prices. The fact that these managers do not always take prudent risks could increase financial fragility. Modelling frameworks that have been developed in order to study bank risk-taking behaviour also offer conflicting mechanism for the competition-risk relationship. One strand of the literature assumes that allocation of bank assets is determined by solving a portfolio problem, focusing on the deposit side of the bank balance sheet (Matutes and Vives, 2000). In this case increased competition would lead to more instability because banks are likely to accept more risky investments in order to cover earnings decline as a result of paying higher deposits rates. Another strand of literature assumes that banks also solve an optimal contracting problem. This kind of moral hazard problem has put competition into a completely new and more positive role. The analysis captures competition on both sides of the bank balance sheet (Boyd and De Nicolo, 2005). In the less competitive market, on the deposit side, banks can earn more rents as previously argued. Nevertheless, banks could also charge higher interest to borrowers on the lending market as well. Facing the higher borrowing rate, borrowers tend to invest in more risky projects; this risk mechanism is exploited further by the moral hazard problem on the bank borrower's side. As a result, banks become more risky in a less competitive market.

One of the early empirical studies on competition and bank risk-taking was conducted by Rhoades and Rutz (1982) on the US. They investigated whether bank managers in concentrated markets would prefer risk-avoidance behaviour in order to enjoy a 'quiet life' due to the lack of competitive pressures. Rhoades and Rutz (1982) found that concentration, measured by the threebank deposit concentration ratio, reduced bank risk-taking alternatively measured by bank profit volatility, the ratio of equity to assets and loans to total assets. Keeley (1990), on the other hand, employed interest rates on large CDs (well-capitalized banks would be less risky and pay lower rates on large CDs) to proxy for risk and applied Tobin's q (the ratio of market to book value) to proxy for market power. Banks with more market power are assumed to have higher market-tobook assets. Keeley (1990) showed that the relaxation of interstate branching barriers statistically reduced bank market power and banks with less market power tend to take-on excessive risk. Using another measure of bank risk, the ratio of loan charge-offs to total loans and loan-loss provisions to total loans, Dick (2006) related these risk proxies to branching relaxation as a proxy for market competition. Banks are expected to take-on more risk because geographic diversification may provide a hedge against increased risk. The results reveal that, following the 
full removal of geographic restrictions in 1994 in the US, both loan charge-offs and loan-loss provisions increased. In contrast, Jayaratne and Strahan (1998) found that branching relaxation sharply reduces bank risk indicated by the decline in loan-loss provisions.

De Nicolo (2000) examined the relationships between bank size, charter value and risk for a sample of listed banks in 21 advanced economies. The market value Z-index was used as an indicator of risk, and this was regressed against bank size measured by the accounting value of bank assets. Larger banks were found to have a higher probability of insolvency (and lower charter values). The results suggest that banks with more market power, indicated by their larger size, take-on more risk. Elaborating on the previous work of De Nicolo (2000), De Nicolo et al. (2004) use a sample of banks from 100 countries to explore the effects of consolidation on risk. They found that at the country level systemic risk measured by an aggregated Z-index was negatively and significantly correlated with concentration, implying that concentrated banking systems are more vulnerable to systemic failure. Boyd et al. (2006) find evidence that concentration in either deposits or loans markets (measured by the Herfindahl-Hirschman index) both lead to higher probabilities of increased risk (as measured by the Z-index). The results are consistent both in the US and for 134 non-industrialized nations. In the same estimation, Boyd et al. (2006) also found that bank risk increases with bank size, supporting the findings by De Nicolo (2000) and De Nicolo et al. (2004).

Yeyati and Micco (2007), on the other hand, used an alternative (non-structural) measure of competition to study the link between competition and risk for banks located in eight Latin American countries. Higher values of the H-statistic are assumed to be associated with a more competitive banking environment. Higher values of the Z-index, in contrast, reflect lower levels of risk. Yeyati and Micco (2007) found a negative correlation between the H-statistic and the inverse of the Z-index, indicating that competition leads banks to take-on less risk. Schaeck et al. (2006) come to similar conclusions, using the H-statistic to examine competition and a duration model of systemic risk across 38 countries between 1980 and 2003. In a recent study Berger et al. (2008) use the non-structural Lerner index as a measure of competition (market power) as well as structural deposit and loan Herfindahl-Hirschman indexes to investigate the competition-risk relationship. Using a variety of bank risk measures (Z-index, non-performing loans to total loans and the equity to assets ratio) and a large sample of banks (8,274 banks from 29 developed nations and 827 from 60 developing nations) they find that in developed countries market power is associated with greater loan risks but lower overall risk (as a consequence of higher capital ratios). For developing nations, they find mixed results according to different measures of market 
power. ${ }^{3}$ In summary, the empirical studies of the direct connection between competition and risk in banking, similar to theoretical arguments, suggest ambiguous results. One of the reasons for the inconclusive findings relates to the different risk and competition measures used in these studies.

\section{Measures of Competition \& the link to Concentration}

Generally, competition has been measured in the banking literature by two different approaches. The structural approach examines competition by relying on the structure of the market. It assumes that markets with only a few large banks could foster collusive behaviour and be associated with higher prices than those with many players. For this reason, the level of competition depends on the number and the size of existing banks. This approach, therefore, uses concentration ratios to infer competition and more concentrated markets would be considered as less competitive.

The non-structural approach, on the other hand, relies on bank behaviour to infer competitive condition. Specifically, competition indexes are estimated based on input price factors and bank revenue equations. In this case, competition in markets can be tested using the H-statistic (or other non-structural measures such as the Lerner index - see Jiménez et al., 2007 and Berger et al., 2008). Therefore, in contrast to the structural approach, researchers using nonstructural approaches, to a certain extent, assume that potential players also impact on the conduct, and subsequently influence competitive condition, of existing players.

One of the non-structural techniques to measure competition is suggested by Panzar and Rosse (1987) who developed the H-statistic to infer the level of competition based on the observation of a bank's behaviour. The H-statistic is calculated from a reduced form revenue equation in which factor price inputs and bank outputs are related. Since this approach observes bank's reaction to changes in input prices, the H-statistic equals the sum of the coefficients of input price factors in respect of bank revenue.

Shaffer (1982) was the first to employ the H-statistic to measure competition in the banking industry and he found that the H-statistic ranged from 0.32 to 0.36 for a sample of banks in New York, indicating that banks operate under monopolistic competition. Measuring competition using the $\mathrm{H}$-statistic has become increasingly popular. Most studies also find that banking markets are typically characterised by monopolistic competition ${ }^{4}$. Only one study, as far

\footnotetext{
${ }^{3}$ Berger et al (2008) also note that the mixed findings for developing countries are likely to be an artefact of the small sample size.

${ }^{4}$ For example see Nathan and Neave (1989), Molyneux et al. (1994, 1996), Hondroyiannis et al. (1999), De Bandt and Davis (2000), Bikker and Haaf (2002), Claessens and Laeven (2004), Coccorese (2004), Gelos and Roldos (2004), Casu and Girardone (2006), Staikouras and Koutsomanoli-Fillipaki (2006), Yuan (2006),
} 
as we are aware (Al-Muharrami et al., 2006) has found evidence of banks primarily earning revenues as if under perfectly competitive conditions. In another aspect, there are studies that compare the degree of competition classified by bank size and found that large banks face fiercer competition than small banks in earning total revenues (De Bandt and Davis, 2000; Bikker and Haaf, 2002) and interest revenues (Staikouras and Koutsomanoli-Fillipaki, 2006). Some attempt to explain the determinants of competition (Claessens and Laeven, 2004; Casu and Girardone, 2006) and show that concentration does not necessarily determine the level of competition. Others, in contrast, use the H-statistic to explain bank performance (Buchs and Mathisen, 2005) or, as we have already discussed, bank risk-taking behaviour (Schaeck et al., 2006, Yeyati and Micco, 2007, Berger et al., 2008).

Another strand of the literature has sought to examine the relationship between concentration and competition. Bikker and Haaf (2002), for example, found that higher concentration levels lead to lower competition (measured using the H-statistic) across 23 countries. However, Demirgüc-Kunt et al. (2004) found that concentration measured by the three-bank concentration ratio leads to lower competition (measured by bank net interest margins) only when regulatory restrictions are eliminated from their estimations. In another study, Beck et al. (2006) found that greater concentration and competition (measured by the lowering of entry and activity restrictions) both lead to reduced systemic risk across their sample of 69 countries. This evidence casts some doubt on the implied inverse link between concentration and competition. Claessens and Laeven (2004) examined the drivers of competition in 50 countries measured by the $\mathrm{H}$-statistic and study found that concentration tended to be positively related to competition and those countries with fewer restrictions tended to be more competitive. Similarly, Casu and Girardone (2006) show no statistically significant link between concentration and competition in European banking, providing conflicting evidence to Bikker and Haaf (2002). Using a sample of eight Latin American countries, Yeyati and Micco (2007) also found that concentration does not appear to restrict competition. A general finding from this literature is that there is no clear relationship between concentration and competition in banking systems and the studies point to the fact (identified by Berger et al., 2004) that competition cannot be accurately gauged by traditional market structure indicators. Coccorese (2009) uses two measures of market power ( arelative Lerner index measure and the Panzar Rosse H-statistic to investigate) to investigate the behaviour of Italian single-branch bank operating as monopolists in small local areas

Matthews et al., (2007), Yeyati and Micco (2007), Yildirim and Philippatos (2007), Coccorese (2009) and Park (2009) 
(municipalities) between 1988 and 2005. He finds that even in monopoly market structures banks are only partially able to exploit market power. A study by Park (2009) that focuses on the impact of increased concentration in the Korean banking following the 1998/9 crisis reveals that (according to the $H$-statistic) the industry remained monopolistically competitive pre- and post-crisis suggesting that concentration had little impact on the competitive environment.

\section{Methodology}

This study uses non-structural H-statistic developed by Panzar and Rosse (1987) to measure competition in South East Asian banking systems. The H-statistic is computed from a reduced form revenue equation and equals the sum of elasticities of bank revenue with respect to input prices. In this paper, the H-statistic is estimated for a pooled country sample using the revenue equation as shown in (1):

$\ln \left(\mathrm{r}_{\mathrm{i}, \mathrm{j}, \mathrm{t}}^{*}\right)=\lambda+\delta_{1} \cdot \ln \left(\mathrm{p}_{1, \mathrm{i}, \mathrm{j}, \mathrm{t}}\right)+\delta_{2} \cdot \ln \left(\mathrm{p}_{2, \mathrm{i}, \mathrm{j}, \mathrm{t}}^{*}\right)+\delta_{3} \cdot \ln \left(\mathrm{p}_{3, \mathrm{i}, \mathrm{j}, \mathrm{t}}\right)+\delta_{4} \cdot \ln \left(\mathrm{b}_{1, \mathrm{i}, \mathrm{j}, \mathrm{t}}\right)+\delta_{5} \cdot \ln \left(\mathrm{b}_{2, \mathrm{i}, \mathrm{j}, \mathrm{t}}\right)+\delta_{6} \cdot \ln \left(\mathrm{b}_{3, \mathrm{i}, \mathrm{j}, \mathrm{t}}\right)+\delta_{7} \cdot \mathrm{d}+\varepsilon_{\mathrm{i}, \mathrm{j}, \mathrm{t}}(1)$

where the ln and subscripts $\mathrm{i}, \mathrm{j}$ and t denote natural logarithms, bank $\mathrm{i}$, country $\mathrm{j}$ and year $\mathrm{t}$, respectively. $r_{i, j, t}^{*}$ is the ratio of gross interest revenue over total assets (as a proxy for output price of loans). $\mathrm{p}_{1, \mathrm{i}, \mathrm{j}, \mathrm{t}}$ is the ratio of interest expenses over total deposits (as a proxy for input price of deposits). $\mathrm{p}_{2, \mathrm{i}, \mathrm{j}, \mathrm{t}}$ is the ratio of personnel expenses over total assets (as a proxy for input price of staff). $\mathrm{p}_{3, \mathrm{i}, \mathrm{j}, \mathrm{t}}$ is the ratio of other operating expenses over total assets (as a proxy for input price of bank physical capital). $b_{1, \mathrm{i}, \mathrm{j}, \mathrm{t}}$ is the ratio of equity over total assets. $\mathrm{b}_{2, \mathrm{i}, \mathrm{j}, \mathrm{t}}$ is the ratio of net loans over total assets. $b_{3, \mathrm{i}, \mathrm{j}, \mathrm{t}}$ is total assets. $\mathrm{d}$ is the time dummies for the years 1999 to 2008 , we drop the year dummy for 1998. $\lambda$ is constant, $\delta_{1}$ to $\delta_{7}$ are coefficients and $\varepsilon_{\mathrm{i}, \mathrm{j}, \mathrm{t}}$ is the error term. The former three independent variables reflect the price factors of bank inputs while the latter three are control variables. These are included to capture the effects of bank capital levels, risk and bank size, respectively, following Claessens and Laeven (2004) and Goddard and Wilson (2009).

The H-statistic equals $\left(\delta_{1}+\delta_{2}+\delta_{3}\right)$ in (1) and is interpreted as follows. $\mathrm{H}$ is less than or equal to zero if a banking firm is operating in monopolistic markets because in these types of markets, when input prices increase, marginal costs should increase. Firms, subsequently, produce less, leading to the reduction in equilibrium output and firms' revenue (Molyneux et al., 1996, p. 35). $\mathrm{H}$ is positive but less than a unity if the market is characterised by monopolistic competition, namely, when input prices increase firms' revenue also increase but by a smaller proportion than costs (Goddard and Wilson, 2009). H equals unity if banking firms are operating 
in a perfectly competitive market or in a monopolistic market which is perfectly contestable. In this case, when input prices change, marginal and average costs also change and the demand adjusts in the long run so selling price and revenue increase by the same proportion as costs.

The advantages of the H-statistic are that it facilitates the use of bank-level data. Also, it enables one to examine the degree of competition for banks belonging to different ownership types, sizes and specializations (Claessens and Laeven, 2004). However, the correct calculation of the H-statistic basically relies on one critical assumption. That is, the markets have to be in long-run equilibrium when the data are observed, which can be tested by computing equation (1) using ROA as the dependent variable as shown in equation (2):

$$
\begin{aligned}
\ln \left(R O A_{i, j, t}\right) & =\lambda+\delta_{1} \cdot \ln \left(p_{1, i, j, t}\right)+\delta_{2} \cdot \ln \left(p_{2, i, j, t}^{*}\right)+\delta_{3} \cdot \ln \left(p_{3, i, j, t}\right) \\
& +\delta_{4} \cdot \ln \left(b_{1, i, j, t}\right)+\delta_{5} \cdot \ln \left(b_{2, i, j, t}\right)+\delta_{6} \cdot \ln \left(b_{3, i, j, t}\right)+\delta_{7} \cdot d+\varepsilon_{i, j, t}
\end{aligned}
$$

where ROA is before-tax return on assets. Because ROA could be a negative number, we transform the dependent variable so that $\operatorname{ROA}^{1}{ }_{\mathrm{i}, \mathrm{j}, \mathrm{t}}=\ln \left(\mathrm{ROA}_{\mathrm{i}, \mathrm{j}, \mathrm{t}}+100\right)^{5}$ where $\mathrm{ROA}_{\mathrm{i}, \mathrm{j}, \mathrm{t}}$ is the original before-tax return on assets. Other variables are similarly defined as those in (1). If longrun equilibrium is satisfied, returns should not be statistically correlated with input prices. That means the sum of elasticities of profits with respect to input prices equals to zero or the E-statistic $=\left(\delta_{1}+\delta_{2}+\delta_{3}\right)=0$. When the market is in disequilibrium, input prices are correlated to returns (Molyneux et al., 1996) and therefore the E-statistic is significantly different from zero.

We use two $\mathrm{H}$-statistics corresponding to using either interest revenue or total revenue as the dependent variables in the reduced form revenue model. $\mathrm{H}^{1}$ refers to the dependent variable, $r_{i, j, t}^{*}$ in (1), in the case where the ratio of gross interest revenue to total assets is used and $\mathrm{H}^{3}$ when $r_{i, j, t}^{*}$ refers to the ratio of total revenue to total assets ${ }^{6}$.

The H-statistic is computed using three different techniques. First, pooled OLS with time dummies is applied. Second, the fixed-effects GLS is employed as commonly applied in the banking literature, in this case $\lambda=\lambda_{\mathrm{i}}$ in equation (1). In the OLS and fixed-effects GLS estimation, the $\mathrm{H}$-statistic equals $\left(\delta_{1}+\delta_{2}+\delta_{3}\right)$ in (1). Third, as a further step to check robustness of our estimates, we compute the H-statistic using the one-step system GMM dynamic panel estimator as suggested by Goddard and Wilson (2009). The model is as follows:

$$
\begin{aligned}
& \ln \left(r_{i, j, t}^{*}\right)=\lambda+\delta_{0} \ln \left(r_{i, j, t-1}^{*}\right)+\delta_{1} \cdot \ln \left(p_{1, i, j, t}\right)+\delta_{2} \cdot \ln \left(p_{2, i, j, t}^{*}\right)+\delta_{3} \cdot \ln \left(p_{3, i, j, t}\right)+\delta_{4} \cdot \ln \left(b_{1, i, j, t}\right) \\
& +\delta_{5} \cdot \ln \left(b_{2, i, j, t}\right)+\delta_{6} \cdot \ln \left(b_{3, i, j, t}\right)+\delta_{7} \cdot d+\varepsilon_{i, j, t}
\end{aligned}
$$

\footnotetext{
${ }_{6}^{5} \mathrm{ROA}$ is in percent.

${ }^{6}$ We also computed $\mathrm{H}^{2}$ which equals $\mathrm{H}^{1}$ but replacing staff costs over total assets by staff costs over loans plus deposits $\left(\mathrm{p}_{2, \mathrm{i}, \mathrm{j}, \mathrm{t}}^{*}\right)$ as a measure of personnel unit price. $\mathrm{H}^{4}$ equals $\mathrm{H}^{3}$ but the similar change is also made. This alternative construction of variables is used for comparison of $\mathrm{H}$-statistic which is, later, shown in Table 5.
} 
In this case, the $H$-statistic equals $\left(\delta_{1}+\delta_{2}+\delta_{3}\right) /\left(1-\delta_{0}\right)$ in (3). All other variables are as defined in (1).

One of the limitations of the H-statistic, as mentioned, lies in the assumption that the market should be observed in long-run equilibrium. Shaffer (2004) suggests that under disequilibrium conditions, even though statistically a unitary $\mathrm{H}$ value is rejected, the actual behaviour of banks may be close to competitive or contestable markets. Goddard and Wilson (2009) argue that, in reality, the speed of adjustment towards equilibrium may be partial rather than instantaneous, driving the market condition out of long-run equilibrium "either occasionally, or frequently, or always". If the adjustment towards equilibrium, responding to changes in input prices, is partial, the static estimation of the H-statistic, as normally applied in empirical studies, could be subject to misspecification. Goddard and Wilson (2009) suggest that, in order to correct for this problem, a dynamic version of the reduced revenue equation should be used to include a lagged dependent variable. And then the long-run equilibrium assumption is no longer necessary because the dynamic estimation enables researchers to incorporate instantaneous adjustments as special circumstances. As such, in the following we use (standard) OLS and fixed-effects GLS estimation to derive $\mathrm{H}$-values as well as the disequilibrium one-step GMM dynamic panel estimator as suggested by Goddard and Wilson (2009). We choose Blundell and Bond's (1998) system GMM estimator instead of Arellano and Bover's (1995) difference GMM estimator for enhanced estimation efficiency ${ }^{7}$.

We choose four different accounting measures of risk in our study. One of these is loan-loss reserves. The general model implied here is that when loans-loss reserves increase, banks are in a more risky position. However, some may argue that loan-loss reserves may be inversely related to risk because well-reserved banks have substantial resources to cover losses ${ }^{8}$. For this reason, loan-loss provisions are used as another risk measure. Contrary to loan-loss reserves, loan-loss provisions are flow items, which reflect the actual sum of money banks have already expended to cover loan losses. Both the aforementioned accounting items are closely related to bank credit risk on a loan-by-loan basis, while risk is today more diversified. So, the

\footnotetext{
${ }^{7}$ Linear dynamic panel regression models include one or more lags of the dependent variable as covariates and contain unobserved individual effects (either fixed or random). Arellano and Bond (1991) use a Generalized Method of Moments (GMM) estimator for such models, known as the difference GMM. The lagged exogenous variables values (levels) constitute legitimate instruments for the first-differenced, lagged dependent variable. However, these lagged variables may provide little information about the first differences (Arellano and Bover, 1995; Blundell and Bond, 1998). Building on the work of Arellano and Bover (1995), Blundell and Bond (1998) developed a system estimator that exploits additional moment conditions on both first-differences and levels, with lagged first-differences of the series employed as instruments in the levels equation. The system GMM estimator reduces potential bias in finite samples as well as asymptotic imprecision associated with the difference estimator (Blundell and Bond, 1998).

${ }^{8}$ In addition, because loan-loss reserves are stock items, banks managers may determine the timing of these stocks at their discretion to reduce regulatory costs (Altunbas et al., 2007)
} 
volatility of (net) ROA is used as an additional risk indicator which is assumed to reflect market risk. Finally, the Z-index is used, which is defined as the ratio of the sum of ROA and equity-toasset ratio over the volatility of ROA. The Z-index reflects the thickness of the book value cushion to absorb losses, thus, in contrast to other risk indicators: higher values of $\mathrm{Z}$ means lower risk $^{9}$. While Bongini et al. (2002) and Laeven (2006) highlight the limitations of using accounting based measures of banking sector risk we follow the approach similar to most of the previous literature mainly because of the limited number of listed banks in our South East Asian sample.

In order to investigate the impact of competition on risk, we relate the four abovementioned risk indicators to six $\mathrm{H}$-statistics (two specifications multiplied by three modelling techniques) using robust OLS. We specify an equation that includes variables derived from various studies on risk, competition and capital regulation in banking ${ }^{10}$. The model to be estimated is as follows:

$$
\begin{aligned}
\text { Risk }_{\mathrm{i}, \mathrm{j}, \mathrm{t}} & =\alpha+\beta_{1} \cdot \text { Competition }_{\mathrm{j}}+\beta_{2} \cdot \text { Size }_{\mathrm{i}, \mathrm{j}, \mathrm{t}}+\beta_{3} \cdot{\text {. } \text { Liquidity }_{\mathrm{i}, \mathrm{j}, \mathrm{t}}+\beta_{4} \cdot \text { Off }_{\text {balance }} \mathrm{i}, \mathrm{j}, \mathrm{t}}+\beta_{5} \cdot \text { Lending }_{\mathrm{i}, \mathrm{j}, \mathrm{t}} \\
& +\beta_{6} \cdot \text { Foreign.share }_{\mathrm{i}, \mathrm{j}, \mathrm{t}}+\beta_{7} \cdot \text {.Interest.rate }_{\mathrm{j}, \mathrm{t}}+\beta_{8} \cdot \text { Concentration }_{\mathrm{j}, \mathrm{t}}+\beta_{9} \cdot \text { Re gulation }_{\mathrm{j}}+\beta_{10} \cdot \text { Dummy }+\varepsilon_{\mathrm{i}, \mathrm{j}, \mathrm{t}}(4)
\end{aligned}
$$

The subscripts $\mathrm{i}, \mathrm{j}$ and $\mathrm{t}$ denote bank $\mathrm{i}$ in country $\mathrm{j}$ at time $\mathrm{t}$. Risk $\mathrm{i}_{\mathrm{i}, \mathrm{j}}$ are the risk indicators, alternatively, the ratio of loan-loss reserves over total loans; the ratio of loan-loss provisions over total loans; the volatility of bank after-tax return on assets (the deviation of individual bank's ROA from the sample mean within one year) and the natural logarithm of the Z-index, which is defined as the ratio of the sum of ROA and equity-to-asset ratio over the volatility of ROA. ${ }^{11}$ Competition $_{\mathrm{j}}$ is measured by the various H-statistics computed from equations (1) and (3). Size $\mathrm{i}_{\mathrm{i}, \mathrm{j}, \mathrm{t}}$ is the natural logarithm of total assets. We control for bank size as it has been found that larger banks face more competitive pressures (De Bandt and Davis, 2000) and may take on higher levels of risk (De Nicolo, 2000). We include bank Liquidity ${ }_{\mathrm{i}, \mathrm{j}, \mathrm{t}}$, the ratio of liquid to total deposits, as one would expect that highly liquid banks encounter less risk because they have excess reserves to cover losses in the case of a crisis, although there is also evidence (Wagner, 2006) that

\footnotetext{
${ }^{9}$ Z-index captures three important components. First, it includes ROA, which is widely used as a measure of bank performance. Second, it includes ROA volatility, a measure of risk used in bank financial management. Thirdly, the index incorporates the bank equity-to-asset ratio (the reciprocal of the equity multiplier). The Zindex has been widely used as measure of the 'safety and soundness' of a banking system (Nash and Sinkey, 1997, p. 96). Z-index has been used to measure banking sector risk by, for example, Nash and Sinkey (1997), De Nicolo (2000), De Nicolo et al. (2004), Boyd et al. (2006), Yeyati and Micco (2007) and Uhde and Heimeshoff (2009)

${ }^{10}$ See Jagtiani et al., 1995; De Bandt and Davis, 2000; De Nicolo, 2000; Bikker and Haaf, 2002; Claessens and Leaven, 2004; Demirgüc-Kunt et al., 2004; Gelos and Roldos, 2004; Gonzalez, 2005; Beck et al., 2006; Casu and Girardone, 2006; Wagner, 2006; Altunbas et al., 2007; Carbo et al., 2009; and Uhde and Heimeshoff, 2009. ${ }^{11}$ Because the Z-index can take large negative values, we adjust the value by taking the logarithm of (Z-index + 150)
} 
suggests liquid banks tend to be more risky. The following two bank-level explanatory variables relate to the bank's off-balance sheet items and lending. Off.balance $e_{i, j, t}$ is the ratio of off-balance sheet items to total assets and this is included to account for the non-traditional area of bank's business. Angbazo (1997) has shown that off-balance sheet activity can help banks diversify revenue streams and reduce risk whereas Stiroh (2004) suggests the opposite, particularly if there is a large trading component yielding volatile income. Lending $\mathrm{i}_{\mathrm{i}, \mathrm{j}}$ is the ratio of net loans over total assets and is included to account for bank lending behaviour as this has been shown to be positively related to risk (Altunbas et al., 2007). Foreign.share $\mathrm{i}_{\mathrm{i}, \mathrm{t}}$ relates to the proportion of individual bank shares owned by foreigners and is included since foreign ownership may intensify competition as suggested by Gelos and Roldos (2004) and, therefore, could influence bank risk-taking behaviour. The Interest.rate ${ }_{j, t}$ variable reflects the real interest lending rate within the respective countries. This is included to reflect a country's overall macroeconomic condition as banks that operate in countries with higher real interest rates tend to face lower risk (Beck et al., 2006) because of the associated lower level of inflation. We also include a Concentration $n_{j, t}$ variable, (the ratio of the three largest bank's assets over total banking sector assets) to investigate whether market structure influences risk (Beck et al., 2006, Berger et al., 2008, Uhde and Heimeshoff, 2009).

It is widely recognized that more restricted banking systems are shown to hinder competition (Claessens and Laeven, 2004) and can also induce incentives for banks to take-on risk (Barth et al., 2001; Gonzalez, 2005). As such, we include a composite indicator to account for the restrictiveness of the regulatory environment. Our Regulation $\mathrm{j}_{\mathrm{j}}$ variable is a composite score reflecting bank activity restrictions, banking entry requirements and diversification opportunities. Higher scores reflect more restricted banking environments. Activity restrictions reflect the ability of banks to be involved in securities, insurance and real estate activities; banking entry requirements reflect the types of legal submissions required to obtain a banking license; and diversification reflects whether there are explicit guidelines for asset diversification and whether banks are allowed to make loans abroad or not. This is obtained from Barth et al. (2001) and available from Barth et al. (2006). We also include yearly dummy variables from 1998 through 2008 (dropping the year dummy for 1998).

\section{Data and results}


The data used in this study comprises financial information for commercial banks ${ }^{12}$ from four South East Asian countries: Indonesia, Malaysia, Philippines and Vietnam, from 1998 to 2008. Bank-level data for Indonesia, Malaysia and Philippines are obtained from the Bankscope database of IBCA. Data for commercial banks in Vietnam are collected from individual banks and the State Bank of Vietnam. Foreign share information is obtained from a variety of sources. For foreign banks in Vietnam, the ownership information is obtained from the State Bank of Vietnam. For those in other countries, foreign shares are identified adopting following steps. First, the ownership information is checked from Bankscope. If not available, we use individual bank website information to date the percentage of share hold by foreign partners during the period of study. Then, Thomson Financial is also used to check for publicized M\&A deals. Finally, the foreign share is cross-checked with previous studies ${ }^{13}$. Interest rate data are obtained from the World Bank, World Development Indicators. The concentration index is from Beck et al. (2000) (and updated to 2008) and the Regulation index is from Barth et al. (2001) (available in Barth et al., 2006).

In this section, we first report the $\mathrm{H}$-statistics which are computed using three different estimators under two specifications. The pooled OLS regression is applied to the data first; then, the fixed-effects estimator is employed; finally, the dynamic panel generalized method of moments (GMM) model developed by Blundell and Bond (1998) is used. Second, the H-statistics from these estimators are compared. Third, the results from the second-stage regressions on competition and risk are reported.

\subsection{The pooled OLS and fixed-effects GLS estimates of the $H$-statistic ${ }^{14}$}

The estimates using equation (1) are shown in Tables 1 and 2, respectively. Overall, input prices of deposits are significantly correlated with bank revenues in all estimates at the $1 \%$ level. Most of other input prices are also positively and significantly correlated with either interest or total revenue in both regressions, except for the case of the price of physical assets for banks in the Philippines, estimated using both OLS and fixed effects estimator. These results are consistent with previous studies (Molyneux et al., 1994; Bikker and Haaf, 2002; Casu and Girardone, 2006) which show that the role of the unit price of deposits is the most important in explaining variation in revenues while that of physical capital is the least important. This may suggest that banks with

\footnotetext{
12 Total number of bank-year observations between 1998 and 2008 amounted to 1216, distributed as follows, Indonesia: 447, Malaysia: 261, Philippines: 311 and Vietnam: 197.

${ }^{13}$ These include Chou (2000), Montreevat (2000), Tschoegl (2001), Chua (2003), Coppel and Davies (2003), Foceralli (2003), Tschoegl (2003), Bekaert and Harvey (2004), Detragiache and Gupta (2004), Megginson (2005). Other sources are ASEAN Bankers Association (regional updates), World Bank (2000), McMillan (2002), Montlake (2003), the US Embassy in Jakarta (2005).

${ }^{14}$ This is estimated for a pooled country sample yielding one H-statistic for each country. We have tried to compute yearly H-statistics following Molyneux et al. (1994) and Yeyati and Micco (2007).
} 
greater funds need higher unit costs of labour and physical capital to intermediate these funds into earning assets and therefore gain higher revenue. Other independent (control) variables, to a large extent, also reveal positive coefficients, suggesting that in South East Asia during the study period, banks with greater equity capital, loans and assets size earned higher revenues (The exception being for the Malaysia in estimates derived via FE).

The H-statistics are all significantly different from zero and unity suggesting that banks in the region earn revenues as if operating under monopolistic competition. This result is consistent with most earlier empirical findings (see Appendix I).

\section{TABLES $1 \& 2$ around here}

\subsection{Tests for long-run equilibrium condition}

Because the H-statistic is based on an assumption of long-run equilibrium, we conduct the equilibrium test by estimating equation (2) using OLS and fixed-effects corresponding to those methods used to estimate the $\mathrm{H}$-statistic. The E-statistics from the equilibrium tests, displayed in Table 3, show that the behaviour of banks in most cases are observed in long-run equilibrium between 1998 and 2008 although the banking systems of Indonesia and the Philippines exhibited some evidence of disequilibrium conditions (using OLS estimates).

\section{TABLES 3 around here}

The disequilibrium conditions found in Indonesia and the Philippines raise certain concerns because the computation of the H-statistic breaks the critical assumption. The result is again in-line with previous empirical evidence (see Appendix I). This is supported in arguments by Goddard and Wilson (2009) who state that in practice adjustments towards long-run equilibrium are not always instantaneous. In this case, inferring competition conditions from the $\mathrm{H}$-statistic for Indonesia and the Philippines using these estimates are likely to be biased.

\subsection{Static versus dynamic H-statistic}

In order to deal with the non- equilibrium conditions we adopt the dynamic panel estimator following Goddard and Wilson (2009) to compute the H-statistic.

\section{TABLES 4 and 5 around here}

The results of the dynamic H-statistics are reported in Table 4. First, regarding the lagged dependent variables, the positive and statistically significant coefficients show a persistence of 
revenue earned by banks in Indonesia, Malaysia and the Philippines. Similar to the results for the H-statistic estimated via OLS and fixed-effects, the unit price of funds shows a positive and statistically significant relationship with bank revenues in all cases, stressing the importance of deposit price inputs. For the other two unit prices of inputs, as well as the coefficients of variables reflecting bank capital, risk and size, the results are broadly in line with the results found from the OLS and FE estimators. The Hansen and second order auto-covariance tests (AR2) show that there are no over-identifying restrictions and no circumstance of second-order autocorrelation.

Table 5 compares the $\mathrm{H}$-statistics derived from the different estimation approaches. In general, the dynamic panel estimates produce higher values of the H-statistic than OLS and GLS. This evidence is consistent with the findings of Goddard and Wilson (2009) who note that traditional estimates of the $\mathrm{H}$-statistic that rely on the restrictive assumption of long-run equilibrium tend to understate the level of competition in banking markets.

\subsection{Evidence on the impact of competition on risk}

The results reported in Table 6, 7 and 8, show that competition does not induce incentives for banks to take-on more risk. Most of our estimates show an inverse relationship between competition and risk statistically significant at the $1 \%$ level. These findings concur with the results of Jayaratne and Strahan (1998), De Nicolo (2000), Boyd et al. (2006), Yeyati and Micco (2007) and Koetter and Poghosyan (2009), but conflict with those reported by Rhoades and Rutz (1982), Keeley (1990) and Dick (2006). We also find some evidence that large banks are less likely to be involved in risky activities compared with small banks. This maybe because of the realization of efficiency benefits via economies of scale or risk reduction through diversification (Liang and Rhoades, 1988; Demsetz and Strahan, 1997; Shiers, 2002). Surprisingly, banks with higher volumes of lending tend to face lower level of risk (reflected in a lower level of loan loss reserve). We actually find positive relationship between lending and risk over the period from 1998 to 2004 but this reverses (presumably because of the booming SE Asian economies) when the study period is extended to 2008. We also find evidence that foreign banks are safer than their domestic counterparts. Liquidity fails to enter the regressions significantly, indicating no significant impact on bank's risk-taking behaviour, while off-balance sheet shows some evidence of positive impact on bank's riskiness, albeit the coefficients are rather small (near zero). Concerning country-level variables, banks in countries with higher real interest rates tend to face lower risk. (In other words, those countries with higher inflation rates have banking systems more prone to risk). More concentrated banking markets also appear to have lower levels of risk (Uhde and Heimeshoff, 2009). Both of these results are consistent with the findings by Beck et al. (2006). The same effects of competition, measured by the H-statistic, and concentration on bank 
risk again cast certain doubts on the traditionally expected link between concentration and competition. The positive relationship between regulation restrictions and bank risks suggest that banks in more restricted systems tend to be involved in riskier activities, a finding consistent with Gonzalez's (2005) evidence on 251 banks in 36 countries and supporting the view in favour of policies that remove banking activity barriers to foster competition.

\section{TABLES 6, $7 \& 8$ around here}

\section{Conclusions}

Our main finding is that competition does not increase bank risk-taking behaviour and the results appear robust to different model specifications, estimation approaches and variable construction. Besides this major finding, we also found that concentration is inversely correlated to bank risk suggesting that more concentrated banking systems are less vulnerable to systemic failure. Regulatory restrictions appear to increase bank risk. The results from our study raise two important implications for policymakers in South East Asian countries. On the one hand, the ongoing consolidation and banking restructuring process in these countries does not necessarily lead to lower competition. Reductions in restrictions on banking activities, particularly on foreign bank operations, appear to lead to higher levels of competition. Increased competition is also shown to reduce bank risk-taking. Therefore, competition policy, which has been launched in South East Asia, can be viewed as a policy action aimed at strengthening the stability of the banking systems. Further areas for future research should seek to link measures of banking system competition to a broader array of market-based risk indicators. This requires information on quoted banks so the analysis would have to span a larger number of countries given the small number of banks publicly quoted in individual Asian countries. Also it may also be interesting to see if the capital structure of banks in these emerging economies helps explain risk and competitive behaviour in these systems.

\section{References}

Al-Muharrami, S., Matthews, K., Khabari, Y., 2006. Market structure and competitive conditions in the Arab GCC banking system. Journal of Banking and Finance 30, 3487-3501. 
Altunbas, Y., Carbo, S., Gardener, E. P. M., Molyneux, P., 2007. Examining the relationships between capital, risk and efficiency in European banking. European Financial Management $13,49-70$.

Angbazo, L., 1997. Commercial bank net interest margins, default risk, interest-rate risk, and offbalance sheet banking, Journal of Banking and Finance 21, 55-87.

Arellano, M., Bond, S., 1991. Some tests of specification for panel data: Monte Carlo evidence and an application to employment equations. Review of Economic Studies 58, 277-297.

ASEAN Bankers Association, 2000, 2001, 2002, 2003, 2004. Regional Updates.

Bank Indonesia, 2000, 2001. Annual Report.

Bank Negara Malaysia, 2000, 2001, 2002, 2003, 2004, 2005. Annual Report.

Bank of Thailand, 1998, 1999, 2000, 2001, 2002, 2003, 2004, 2005. Annual Report.

Barth, J., Caprio, G., Levine, R., 2001. Bank regulation and supervision: what works best?. Policy Research Working Paper No. 2725, World Bank.

Barth, J., Caprio, G., Levine, R., 2006. Rethinking bank regulation: till angels govern. Cambridge University Press, Cambridge, UK.

Baumol, W. J., Panzar, J. C., Willig, R. D., 1982. Contestable market and the theory of industry structure. Harcourt Brace Jovanovich, Sandiego, CA.

Beck, T., Demirgüc-Kunt, A., Levine, R., 2000. A new database on financial development and structure. World Bank Economic Review 14, 597-605.

Beck, T., Demirgüc-Kunt, A., Levine, R., 2006. Bank concentration, competition, and crises: first results. Journal of Banking and Finance 30, 1581-1603.

Bekaert, G., Harvey, C. R., 2004. A chronology of important financial, economic and political events in emerging markets. Duke University.

Berger, A.N., Demirguc-Kunt A., Levine, R., Haubrich, J., 2004. Bank concentration and competition: An evolution in the making, Journal of Money, Credit and Banking 36, 433-451.

Berger, A.N., Klapper, L. F., Turk-Ariss, R., (2009) Bank competition and financial stability. Journal of Financial Services Research 35, 99-118

Bikker, J. A., Haaf, K., 2002. Competition, concentration and their relationship: an empirical analysis of the banking industry. Journal of Banking and Finance 26, 2191-2214.

Bongini, P., Laeven, L., Majnoni., 2002. How good is the market at assessing bank fragility? A horse race between different indicators. Journal of Banking and Finance 26, 1011-1028.

Boyd, J. H., De Nicolo, G., 2005. The theory of bank risk taking and competition revisited. Journal of Finance LX, 1329-1343.

Boyd, J. H., De Nicolo, G., Jalal, A. M., 2006. Bank risk-taking and competition revisited: new theory and new evidence. Working Paper WP/06/297, IMF.

Brunnermeier, M.K., 2009. Deciphering the liquidity and credit crunch 2007-08. Journal of Economic Perspectives 23, 77-100.

Buchs, T., Mathisen, J., 2005. Competition and efficiency in banking: behavioural evidence from Ghana. Working Paper WP/05/17, IMF.

Carbo, S., Humphrey, D., Maudos, J., Molyneux, P., 2009. Cross-country comparisons of competition and pricing power in European banking. Journal of International Money and Finance 28, 115-134.

Carletti, E., Hartmann, P., 2003. Competition and financial stability: what's special about banking?, in: Mizen, P. (Ed.), Monetary History, Exchange Rates and Financial Markets: Essays in Honour of Charles Goodhart, Vol. 2. Edward Elgar, Cheltenham, UK.

Casu, B., Girardone, C., 2006. Bank competition, concentration and efficiency in the single European market. The Manchester School 74, 44-468. 
Chou, C., 2000. Indonesian banks: Survival of the fittest. ADB.

Chua, H. B., 2003. FDI in the financial sector: The experience of ASEAN countries over the last decade. Monetary Authority of Singapore.

Claessens, S., Laeven, L., 2004. What drives bank competition? Some international evidence. Journal of Money, Credit and Banking 36, Part 2, 563-584.

Coccorese, P., 2004. Banking competition and macroeconomic conditions: a disaggregate analysis. Journal of International Financial Markets, Institutions and Money 14, 203-219.

Coccorese, P., 2009. Market power in local banking monopolies. Journal of Banking and Finance 33, 1196-1210.

Coppel, J., Davies, M., 2003. Foreign participation in East Asia's banking sector. International Department, Reserve Bank of Australia.

De Bandt, O., Davis, E. P., 2000. Competition, contestability and market structure in European banking sectors on the eve of EMU. Journal of Banking and Finance 24, 1045-1066.

De Nicolo, G., 2000. Size, charter value and risk in banking: an international perspective. International Finance Discussion No. 689, Board of Governors of the Federal Reserve System.

De Nicolo, G., Bartholomew, P., Zaman, J., Zephirin, M., 2004. Bank consolidation, internationalization and conglomeration: Trends and implications for financial risk. Financial Markets, Institutions and Instruments 13, 173-217.

De Nicolo, G., Loukoianova, E., 2006. Bank Ownership, Market Structure, and Risk. Unpublished Working Paper, IMF.

Delis, M. D., 2009. Competitive conditions in the Central and Eastern European banking systems. Omega, Forthcoming.

Demirgüc-Kunt, A., Laeven, L., Levine, R., 2004. Regulations, market structure, institutions, and the cost of financial intermediation. Journal of Money, Credit and Banking 36, Part 2, 593622.

Demsetz, R. S., Strahan, P. E., 1997. Diversification, size, and risk at Bank Holding Companies. Journal of Money, Credit and Banking 29, 300-313.

Demsetz, R., Saidenberg, M.R., Strahan, P.E., 1996. Banks with something to lose: The disciplinary role of franchise value. Federal Reserve Bank of New York Economic Policy Review Vol. 2, No.2. (October), 1-14.

Detragiache, E., Gupta, P., 2004. Foreign banks in emerging market crises: Evidence from Malaysia. Working Paper WP/04/129, IMF.

Dick, A. A., 2006. Nationwide branching and its impact on market structure, quality and bank performance. Journal of Business 79, 567-592.

Focarelli, D., 2003. The pattern of foreign bank entry in the financial markets of emerging countries. BIS.

G30., 2009. Financial reform: A framework for financial stability. Washington: Group of 30.

Gelos, R. G., Roldos, J., 2004. Consolidation and market structure in emerging banking systems. Emerging Markets Review 5, 39-59.

Ghosh, S.R., 2006. East Asian finance: The road to robust markets. World Bank.

Goddard, J., Wilson, J. O. S., 2009. Competition in banking: A disequilibrium approach. Journal of Banking and Finance, Forthcoming.

Gonzalez, F., 2005. Bank regulation and risk-taking incentives: an international comparison of bank risk. Journal of Banking and Finance 29, 1153-1184.

Hempell, H. S., 2002. Testing for competition among German banks. Discussion Paper No. 04/02, Economic Research Centre, Deutsche Bundesbank. 
Hondroyiannis, G., Lolos, S., Papapetrou, E., 1999. Assessing competitive conditions in the Greek banking system. Journal of International Financial Markets, Institutions and Money 9, 377-391.

Jagtiani, J., Saunders, A., Udell, G., 1995. The effect of bank capital requirements on bank offbalance sheet financial innovations. Journal of Banking and Finance 19, 647-658.

Jayaratne, J., Strahan, P. E., 1998. Entry restrictions, industry evolution, and dynamic efficiency: Evidence from commercial banking. Journal of Law and Economics XLI, 239-273.

Jimenez, G., Lopez, J., Saurina, J., 2007. How does competition impact bank risk taking?. Banco de Espana Working Paper.

Keeley, M. C., 1990. Deposit insurance, risk and market power in banking. The American Economic Review 80, 1183-1200.

Koetter, M., Poghosyan, T., 2009. The identification of technology regimes in banking: Implications for the market power-fragility nexus. Journal of Banking and Finance 33, 1413 1422.

Laeven, L., 2006. Banking sector performance in East Asian countries: the effects of competition, diversification, and ownership. A background paper for 'East Asian Finance: The Road to Robust Markets. World Bank. Mimeo.

Liang, N., Rhoades, S. A., 1988. Geographic diversification and risk in banking. Journal of Economics and Business 40, 271-284.

Llewellyn, D.T. (2007). The Northern Rock crisis: A multi-dimensional problem waiting to happen. Journal of Financial Regulation and Compliance 16, 35-58.

Marcus, A.J., 1984. Deregulation and bank financial policy. Journal of Banking and Finance 8, 557-565.

Matthews, K., Ismail, M., 2006. Efficiency and productivity growth of foreign commercial banks in Malaysia. Economics Working Paper No. E2006/2. Cardiff Business School.

Matthews, K., Murinde, V., Zhao, T., 2007. Competitive conditions among the major British banks. Journal of Banking and Finance 31, 2025-2042.

Matutes, C., Vives, X., 2000. Imperfect competition, risk taking and competition in banking. European Economic Review 44, 1-34.

McMillan, A. F., 2002. The players in Indonesia's big sale. CNN News.

Megginson, W. L., 2005. The economics of bank privatization. Journal of Banking and Finance 29, 1931-1980.

Milne, A. (2009). The Fall of the House of Credit. Cambridge: Cambridge University Press

Molyneux, P., Lloyd-Williams, D. M., Thornton, J., 1994. Competitive conditions in European banking. Journal of Banking and Finance 18, 445-459.

Molyneux, P., Thornton, J., Lloyd-Williams, D. M., 1996. Competition and market contestability in Japanese commercial banking system. Journal of Economics and Business 48, 33-45.

Montlake, S., 2003. Indonesia prepares for life after IMF. The Banker. October.

Montreevat, S., 2000. Impact of foreign bank entry on the Thai banking sector: initial stage of bank restructuring. Working Paper on Economics and Finance No. 5, Institutes for Southeast Asian Studies.

Nash, R. C., Sinkey, J. F., 1997. On competition, risk, and hidden assets in the market for bank credit cards. Journal of Banking and Finance 21, 89-112.

Nathan, A., Neave, E. H., 1989. Competition and Contestability in Canada's financial system: empirical results. Canadian Journal of Economics 22, 576-594.

Panzar, J. C., Rosse, J. N., 1987. Testing for monopoly equilibrium. Journal of Industrial Economics 35, 443-456. 
Park, K. H., 2009. Has bank consolidation in Korea lessened competition? The Quarterly Review of Economics and Finance 49, 651-667.

Rhoades, S. A., Rutz, R. D., 1982. Market power and firm risk: a test of the 'quiet life' hypothesis. Journal of Monetary Economics 9, 73-85.

Schaeck, K., Cihak, M., Wolfe, S., 2006. Are more competitive banking systems more stable? Unpublished Working Paper No. 143, IMF.

Shaffer, S., 1982. Non-structural test for competition in financial markets. Proceedings of Federal Reserve Bank of Chicago: Bank structure and competition. Chicago.

Shaffer, S., 2004. Patterns of competition in banking. Journal of Economics and Business 56, 287-313.

Shiers, A., 2002. Branch banking, economic diversity and bank risk. The Quarterly Review of Economics and Finance 42, 57-598.

Staikouras, C. K., Koutsomanoli-Fillipaki, A., 2006. Competition and concentration in the new European banking landscape. European Financial Management 12, 443-482.

State Bank of Vietnam, 2000, 2001, 2002, 2003. Annual Report.

Stiroh, K. J., 2004. Diversification in banking: is noninterest income the answer? Journal of Money, Credit and Banking 36, 853-882.

The US Embassy in Jakarta, 2005. Indonesia: economic and financial highlights. March 2005.

Tschoegl, A. E., 2001. The international expansion of the Singapore's largest banks. Working Paper No. 01-20, The Wharton Financial Institutions Centre, The Wharton School of the University of Pennsylvania.

Tschoegl, A. E., 2003. Financial crises and the presence of foreign banks. Working Paper No. 0335, The Wharton Financial Institutions Centre, The Wharton School of the University of Pennsylvania.

Turk-Ariss, R., 2009. Competitive behavior in Middle East and North Africa banking systems. The Quarterly Review of Economics and Finance 49, 693-710.

Uhde, A., Heimeshoff, U., 2009. Consolidation in banking and financial stability in Europe: Empirical evidence. Journal of Banking and Finance 33, 1299-1311.

Wagner, W., 2007. The liquidity of bank assets and banking stability. Journal of Banking and Finance 31, 121-139.

World Bank, 2000. Thailand Economic Monitor. February.

Yeyati, E. L., Micco, A., 2007. Concentration and foreign penetration in Latin American banking sectors: Impact on competition and risk. Journal of Banking and Finance 31, 1633-1647.

Yildirim, H. S., Philippatos, G. C., 2007. Restructuring, consolidation and competition in Latin American banking markets. Journal of Banking and Finance 31, 629-639.

Yuan, Y., 2006. The state of competition of the Chinese banking industry. Journal of Asian Economics 17, 519-534. 


\section{APPENDIX 1 here}


Table 1 Competitive test --- Pooled OLS estimates 1998-2008

\begin{tabular}{|c|c|c|c|c|c|c|c|c|}
\hline & \multicolumn{2}{|c|}{ Indonesia } & \multicolumn{2}{|c|}{ Malaysia } & \multicolumn{2}{|c|}{ Philippines } & \multicolumn{2}{|c|}{ Vietnam } \\
\hline & Spec 1 & Spec 3 & Spec 1 & Spec 3 & Spec 1 & Spec 3 & Spec 1 & Spec 3 \\
\hline \multirow[t]{2}{*}{$\ln (\mathrm{p} 1)$} & $0.243 * * *$ & $0.143 * * *$ & $0.696 * * *$ & $0.683 * * *$ & $0.264 * * *$ & $0.279 * * *$ & $0.573 * * *$ & $0.450 * * *$ \\
\hline & $(0.000)$ & $(0.000)$ & $(0.000)$ & $(0.000)$ & $(0.000)$ & $(0.000)$ & $(0.000)$ & $(0.000)$ \\
\hline \multirow[t]{2}{*}{$\ln (p * 2)$} & $0.206 * * *$ & $0.127 * * *$ & -0.019 & 0.047 & $0.276 * * *$ & $0.238 * * *$ & $0.066^{* *}$ & $0.076 * * *$ \\
\hline & $(0.000)$ & $(0.000)$ & $(0.533)$ & $(0.263)$ & $(0.000)$ & $(0.000)$ & $(0.021)$ & $(0.007)$ \\
\hline \multirow[t]{2}{*}{$\ln (\mathrm{p} 3)$} & $0.077 * * *$ & $0.151 * * *$ & 0.006 & $0.164 * * *$ & -0.009 & -0.005 & $0.123 * * *$ & $0.174 * * *$ \\
\hline & $(0.000)$ & $(0.000)$ & $(0.810)$ & $(0.000)$ & $(0.867)$ & $(0.921)$ & $(0.000)$ & $(0.000)$ \\
\hline \multirow[t]{2}{*}{$\ln (\mathrm{b} 1)$} & $0.042 * * *$ & $0.040 * * *$ & $0.072 * * *$ & $0.091 * * *$ & $0.103 * * *$ & $0.121 * * *$ & -0.020 & -0.023 \\
\hline & $(0.001)$ & $(0.005)$ & $(0.000)$ & $(0.001)$ & $(0.000)$ & $(0.000)$ & $(0.287)$ & $(0.229)$ \\
\hline \multirow[t]{2}{*}{$\ln (\mathrm{b} 2)$} & $0.075^{* * *}$ & $0.061 * * *$ & $0.067 * * *$ & $0.042 *$ & $0.203 * * *$ & $0.127 * * *$ & $0.051 *$ & $0.075 * * *$ \\
\hline & $(0.000)$ & $(0.009)$ & $(0.000)$ & $(0.069)$ & $(0.000)$ & $(0.000)$ & $(0.067)$ & $(0.007)$ \\
\hline \multirow[t]{2}{*}{$\ln (\mathrm{b} 3)$} & $0.025 * * *$ & $0.027 * * *$ & $0.061 * * *$ & 0.007 & $0.010^{* *}$ & 0.006 & -0.004 & $-0.007 * *$ \\
\hline & $(0.000)$ & $(0.000)$ & $(0.000)$ & $(0.564)$ & $(0.036)$ & $(0.127)$ & $(0.294)$ & $(0.045)$ \\
\hline \multirow[t]{2}{*}{ constant } & $1.731 * * *$ & $2.239 * * *$ & -0.157 & $0.529 * * *$ & $0.338 *$ & $0.784 * * *$ & $0.799 * * *$ & $1.130 * * *$ \\
\hline & $(0.000)$ & $(0.000)$ & $(0.231)$ & $(0.004)$ & (0.068) & $(0.000)$ & $(0.000)$ & $(0.000)$ \\
\hline Obs. & 434 & 434 & 240 & 240 & 307 & 307 & 169 & 169 \\
\hline $\mathrm{R}$-squared & 0.72 & 0.65 & 0.90 & 0.78 & 0.58 & 0.59 & 0.90 & 0.88 \\
\hline H-statistic & 0.53 & 0.42 & 0.68 & 0.89 & 0.53 & 0.51 & 0.76 & 0.70 \\
\hline F-test $\mathrm{H}=0$ & $352.61 * * *$ & $181.77 * * *$ & $485.19 * * *$ & $415.99 * * *$ & $112.93 * * *$ & $143.01 * * *$ & $744.82 * * *$ & $651.95 * * *$ \\
\hline F-test $\mathrm{H}=1$ & $287.60 * * *$ & $345.37 * * *$ & $103.99 * * *$ & $5.86^{* * *}$ & $87.87 * * *$ & $129.33 * * *$ & $72.74 * * *$ & $119.60 * * *$ \\
\hline
\end{tabular}


Table 2 Competitive test --- Fixed effects estimates 1998-2008

\begin{tabular}{|c|c|c|c|c|c|c|c|c|}
\hline & \multicolumn{2}{|c|}{ Indonesia } & \multicolumn{2}{|c|}{ Malaysia } & \multicolumn{2}{|c|}{ Philippines } & \multicolumn{2}{|c|}{ Vietnam } \\
\hline & Spec 1 & Spec 3 & Spec 1 & Spec 3 & Spec 1 & Spec 3 & Spec 1 & Spec 3 \\
\hline \multirow[t]{2}{*}{$\ln (\mathrm{p} 1)$} & $0.375 * * *$ & $0.332 * * *$ & $0.494 * * *$ & $0.372 * * *$ & $0.389 * * *$ & $0.391 * * *$ & $0.576 * * *$ & $0.475 * * *$ \\
\hline & $(0.000)$ & $(0.000)$ & $(0.000)$ & $(0.000)$ & $(0.000)$ & $(0.000)$ & $(0.000)$ & $(0.000)$ \\
\hline \multirow[t]{2}{*}{$\ln (\mathrm{p} * 2)$} & $0.141 * * *$ & $0.139 * * *$ & 0.009 & $0.101 * *$ & $0.102 * *$ & 0.069 & 0.051 & $0.093 * * *$ \\
\hline & $(0.000)$ & $(0.003)$ & $(0.816)$ & $(0.032)$ & $(0.036)$ & $(0.170)$ & $(0.150)$ & $(0.007)$ \\
\hline \multirow[t]{2}{*}{$\ln (\mathrm{p} 3)$} & $0.048 * *$ & $0.088 * * *$ & 0.007 & $0.071 * *$ & 0.052 & 0.047 & $0.133 * * *$ & $0.134 * * *$ \\
\hline & $(0.025)$ & $(0.003)$ & $(0.821)$ & $(0.049)$ & $(0.214)$ & $(0.272)$ & $(0.000)$ & $(0.000)$ \\
\hline \multirow[t]{2}{*}{$\ln (\mathrm{b} 1)$} & 0.010 & -0.009 & $0.089 * *$ & $0.114 * *$ & $0.066 * * *$ & $0.155 * * *$ & -0.010 & -0.002 \\
\hline & $(0.456)$ & $(0.643)$ & $(0.028)$ & $(0.019)$ & $(0.000)$ & $(0.000)$ & $(0.680)$ & $(0.932)$ \\
\hline \multirow[t]{2}{*}{$\ln (\mathrm{b} 2)$} & $0.084 * * *$ & -0.029 & $0.072 *$ & $0.087 *$ & $0.069 * *$ & 0.034 & 0.035 & 0.028 \\
\hline & $(0.000)$ & $(0.377)$ & $(0.068)$ & $(0.064)$ & $(0.038)$ & $(0.322)$ & $(0.347)$ & $(0.435)$ \\
\hline \multirow[t]{2}{*}{$\ln (\mathrm{b} 3)$} & -0.009 & -0.002 & -0.066 & $-0.142 * *$ & 0.014 & 0.035 & -0.022 & -0.029 \\
\hline & $(0.765)$ & $(0.954)$ & $(0.192)$ & $(0.021)$ & $(0.697)$ & $(0.357)$ & $(0.280)$ & $(0.130)$ \\
\hline \multirow[t]{2}{*}{ constant } & $1.605 * * *$ & $2.272 * * *$ & $1.181 * *$ & $2.140 * * *$ & $0.775 * * *$ & $0.772 * * *$ & $0.956^{* * *}$ & $1.434 * * *$ \\
\hline & $(0.000)$ & $(0.000)$ & $(0.023)$ & $(0.001)$ & $(0.006)$ & $(0.008)$ & $(0.001)$ & $(0.000)$ \\
\hline Obs. & 434 & 434 & 240 & 240 & 307 & 307 & 169 & 169 \\
\hline R-squared & 0.68 & 0.59 & 0.61 & 0.32 & 0.48 & 0.39 & 0.87 & 0.83 \\
\hline H-statistic & 0.56 & 0.56 & 0.51 & 0.54 & 0.54 & 0.51 & 0.76 & 0.70 \\
\hline F-test $\mathrm{H}=0$ & $171.78 * * *$ & $89.63 * * *$ & $118.52 * * *$ & $93.83 * * *$ & $87.08 * * *$ & $71.16 * * *$ & $464.42 * * *$ & $438.60 * * *$ \\
\hline F-test $\mathrm{H}=1$ & $103.01 * * *$ & $55.72 * * *$ & $109.27 * * *$ & $66.19 * * *$ & $61.54 * * *$ & $67.21 * * *$ & $46.01 * * *$ & $79.88 * * *$ \\
\hline
\end{tabular}

Notes: P-values are in parentheses. Spec 1 uses the natural logarithm of interest income over total assets while Spec 3 uses the natural logarithm of total income over total assets as the dependent variable in equation (1). Table 1 presents the results of $\mathrm{H}$ statistic estimated by pooled OLS and Table 2 presents the results of fixed-effects. The model is estimated with time dummies (but not reported $) . \operatorname{Ln}(\mathrm{p} 1)=$ natural logarithm of interest expenses over deposits; $\ln \left(\mathrm{p}^{*} 2\right)=$ natural logarithm of personnel expenses over total assets; $\ln (\mathrm{p} 3)$ = natural logarithm of other operating expenses over total assets; $\ln (\mathrm{b} 1)=$ natural logarithm of net loans over total assets; $\ln (\mathrm{b} 2)=$ natural logarithm of equity capital over total assets; $\ln (\mathrm{b} 3)=$ natural logarithm of total assets. * Significant at 0.1 level, ** significant at 0.05 level and $* * *$ significant at 0.01 level 
Table 3 Equilibrium test --. OLS and Fixed effects estimates 1998-2008

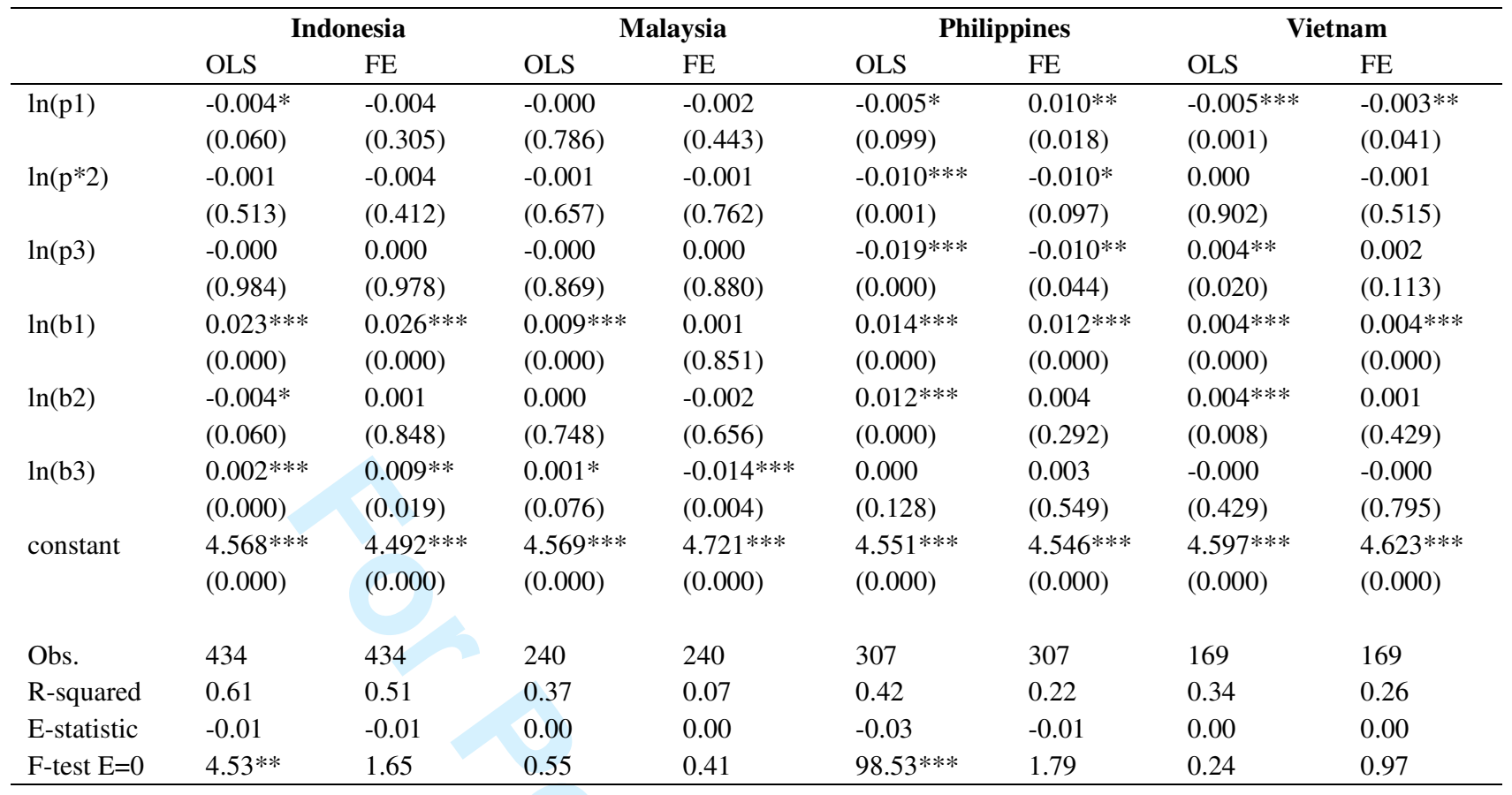

Notes: P-values are in parentheses. OLS and FE mean the results from the estimation of (2), using pooled OLS and fixed-effects respectively. Both models are estimated with time dummies (but not reported). $\operatorname{Ln}(\mathrm{p} 1)=$ natural logarithm of interest expenses over deposits; $\ln \left(\mathrm{p}^{* 2}\right)=$ natural logarithm of personnel expenses over total assets; $\ln (\mathrm{p} 3)=$ natural logarithm of other operating expenses over total assets; $\ln (\mathrm{b} 1)=$ natural logarithm of net loans over total assets; $\ln (\mathrm{b} 2)=$ natural logarithm of equity capital over total assets; $\ln (\mathrm{b} 3)=$ natural logarithm of total assets. * Significant at 0.1 level, $* *$ significant at 0.05 level and $* * *$ significant at 0.01 level 
Table 4 Competitive test --- Dynamic GMM estimates 1998-2008

\begin{tabular}{|c|c|c|c|c|c|c|c|c|}
\hline & \multicolumn{2}{|c|}{ Indonesia } & \multicolumn{2}{|c|}{ Malaysia } & \multicolumn{2}{|c|}{ Philippines } & \multicolumn{2}{|c|}{ Vietnam } \\
\hline & Spec 1 & Spec 3 & Spec 1 & Spec 3 & Spec 1 & Spec 3 & Spec 1 & Spec 3 \\
\hline \multirow[t]{2}{*}{$\mathrm{L} \cdot \ln \left(\mathrm{r}^{*} 1\right)$} & $0.275 * * *$ & 0.035 & $0.390 * * *$ & $0.320 * * *$ & $0.314 * *$ & $0.229 *$ & 0.082 & 0.123 \\
\hline & $(0.005)$ & $(0.787)$ & $(0.000)$ & $(0.000)$ & $(0.028)$ & $(0.085)$ & $(0.179)$ & $(0.170)$ \\
\hline \multirow[t]{2}{*}{$\ln (\mathrm{p} 1)$} & $0.246^{* * * *}$ & $0.188 * * *$ & $0.482 * * *$ & $0.502 * * *$ & $0.312 * * *$ & $0.291 * * *$ & $0.561 * * *$ & $0.423 * * *$ \\
\hline & $(0.000)$ & $(0.000)$ & $(0.000)$ & $(0.000)$ & $(0.000)$ & $(0.000)$ & $(0.000)$ & $(0.000)$ \\
\hline \multirow[t]{2}{*}{$\ln \left(p^{* 2}\right)$} & $0.137 * * *$ & $0.135 * * *$ & -0.018 & 0.046 & $0.184 * * *$ & $0.133^{* *}$ & 0.039 & 0.037 \\
\hline & $(0.003)$ & $(0.008)$ & $(0.576)$ & $(0.157)$ & $(0.009)$ & $(0.033)$ & $(0.247)$ & $(0.205)$ \\
\hline \multirow[t]{2}{*}{$\ln (\mathrm{p} 3)$} & $0.087 * *$ & $0.148 * * *$ & 0.025 & $0.111 * * *$ & -0.025 & 0.028 & $0.141 * * *$ & $0.198 * * *$ \\
\hline & $(0.012)$ & $(0.002)$ & $(0.284)$ & $(0.000)$ & $(0.680)$ & $(0.663)$ & $(0.000)$ & $(0.000)$ \\
\hline \multirow[t]{2}{*}{$\ln (\mathrm{b} 1)$} & 0.033 & $0.052 *$ & $0.058 * * *$ & $0.068 * *$ & $0.084 * * *$ & $0.133^{* *}$ & $-0.042 *$ & -0.010 \\
\hline & $(0.128)$ & $(0.076)$ & $(0.002)$ & $(0.024)$ & $(0.003)$ & $(0.011)$ & $(0.079)$ & $(0.688)$ \\
\hline \multirow[t]{2}{*}{$\ln (\mathrm{b} 2)$} & $0.070^{* *}$ & -0.007 & $0.070 * * *$ & $0.045^{*}$ & $0.143^{* * *}$ & $0.095^{* *}$ & 0.060 & $0.095^{*}$ \\
\hline & $(0.048)$ & $(0.928)$ & $(0.001)$ & $(0.084)$ & $(0.002)$ & $(0.028)$ & $(0.113)$ & $(0.057)$ \\
\hline \multirow[t]{2}{*}{$\ln (\mathrm{b} 3)$} & $0.014 *$ & $0.020^{*}$ & $0.038 * * *$ & 0.006 & $0.011 * *$ & 0.008 & -0.003 & -0.004 \\
\hline & $(0.072)$ & $(0.052)$ & $(0.000)$ & $(0.687)$ & $(0.018)$ & (0.135) & $(0.449)$ & $(0.311)$ \\
\hline \multirow[t]{2}{*}{ constant } & $0.577 * *$ & $1.524 * * *$ & $-0.401 * * *$ & 0.316 & -0.017 & 0.353 & $0.840 * * *$ & $0.978 * * *$ \\
\hline & $(0.039)$ & $(0.010)$ & $(0.006)$ & $(0.115)$ & $(0.951)$ & $(0.331)$ & $(0.000)$ & $(0.000)$ \\
\hline Obs. & 344 & 344 & 195 & 196 & 232 & 232 & 138 & 138 \\
\hline H-statistic & 0.65 & 0.49 & 0.80 & 0.97 & 0.69 & 0.59 & 0.81 & 0.75 \\
\hline Hansenp & 0.54 & 0.60 & 0.97 & 0.98 & 0.28 & 0.60 & 1.00 & 0.99 \\
\hline $\mathrm{AR}(2)$ & 0.30 & 0.24 & 0.43 & 0.80 & 0.09 & 0.18 & 0.09 & 0.70 \\
\hline
\end{tabular}

Notes: P-values are in parentheses. Spec 1 uses the natural logarithm of interest income over total assets while Spec 3 uses the natural logarithm of total income over total assets as the dependent variable in equation (3). The results are estimated from one-step dynamic panel generalized method of moments developed by Blundell and Bond (1998). $\mathrm{L} \cdot \ln \left(\mathrm{r}^{*} 1\right)=$ natural logarithm of the lagged dependent variable; $\ln (\mathrm{p} 1)=$ natural logarithm of interest expenses over deposits; $\ln \left(\mathrm{p}^{*} 2\right)=$ natural logarithm of personnel expenses over total assets; $\ln (\mathrm{p} 3)=$ natural logarithm of other operating expenses over total assets; $\ln (\mathrm{b} 1)=$ natural logarithm of net loans over total assets; $\ln (\mathrm{b} 2)=$ natural logarithm of equity capital over total assets; $\ln (\mathrm{b} 3)=$ natural logarithm of total assets. 'Hansenp' is the p-value of the Hansen test statistic of over-identifying restrictions, while $\mathrm{AR}(2)$ is the p-value of the second order autocorrelation test statistic. Pvalues of the estimated coefficients are reported in brackets. Year dummies from 1999 through 2008 are included in the model but not reported in the table. ${ }^{*}, *$, and $* * *$ represent 10,5 and 1 percent significance level, respectively. 
Table 5 H-statistic: Comparison of OLS, Fixed Effects and dynamic GMM estimates 1998-2008

\begin{tabular}{rlllllllllllll}
\hline & \multicolumn{4}{c}{ Indonesia } & \multicolumn{4}{c}{ Malaysia } & \multicolumn{3}{c}{ Philippines } & \multicolumn{3}{c}{ Vietnam } \\
Spec & OLS & FE & GMM & OLS & FE & GMM & OLS & FE & GMM & OLS & FE & GMM \\
\hline 1 & 0.525 & 0.564 & 0.647 & 0.684 & 0.510 & 0.800 & 0.531 & 0.543 & 0.686 & 0.762 & 0.761 & 0.808 \\
2 & 0.510 & 0.522 & 0.647 & 0.689 & 0.475 & 0.800 & 0.434 & 0.532 & 0.686 & 0.747 & 0.746 & 0.808 \\
3 & 0.420 & 0.559 & 0.488 & 0.894 & 0.544 & 0.968 & 0.513 & 0.507 & 0.586 & 0.700 & 0.701 & 0.751 \\
4 & 0.413 & 0.565 & 0.509 & 0.879 & 0.520 & 1.000 & 0.426 & 0.495 & 0.606 & 0.683 & 0.676 & 0.734 \\
Mean & 0.467 & 0.552 & 0.573 & 0.786 & 0.512 & 0.892 & 0.476 & 0.520 & 0.641 & 0.723 & 0.721 & 0.775 \\
\hline
\end{tabular}

Note: For brevity, individual coefficients are unreported. Spec $1=$ bank interest revenue over total assets as the dependent variable; unit cost of labour is measured by personnel expenses over total assets, Spec $2=$ unit cost of labour is measured by personnel expenses over loans plus deposits, Spec $3=$ bank total revenue over total assets as the dependent variable, unit cost of labour is measured similarly to Spec 1 , Spec $4=$ the dependent variable is the same as that of Spec 3 but unit cost of labour is measured by personnel expenses over loans plus deposits. All other variables are as defined in equations (1) and (3). OLS, FE and GMM are H-statistics computed using OLS, fixed-effects (applied to equation 1) and generalized method of moments dynamic estimator (applied to equation $3)$, respectively. 
Table 6 Competition (measured using the OLS H-statistic) and risk

\begin{tabular}{|c|c|c|c|c|c|c|c|c|}
\hline & \multicolumn{2}{|c|}{ LLR } & \multicolumn{2}{|c|}{ LLP } & \multicolumn{2}{|c|}{ ROA Volatility } & \multicolumn{2}{|c|}{$\mathbf{Z}$} \\
\hline & $\mathrm{Hb}^{1}$ & $\mathrm{Hb}^{3}$ & $\mathrm{Hb}^{1}$ & $\mathrm{Hb}^{3}$ & $\mathrm{Hb}^{1}$ & $\mathrm{Hb}^{3}$ & $\mathrm{Hb}^{1}$ & $\mathrm{Hb}^{3}$ \\
\hline \multirow[t]{2}{*}{ Competition } & $-19.453 * * *$ & $-10.399 * * *$ & $-5.873 * * *$ & $-3.492 * * *$ & $-3.065 * * *$ & $-1.609 * * *$ & 31.948 & 16.657 \\
\hline & $(0.000)$ & $(0.000)$ & $(0.000)$ & $(0.000)$ & $(0.000)$ & $(0.000)$ & $(0.240)$ & (0.293) \\
\hline \multirow[t]{2}{*}{ Size } & -0.073 & -0.061 & 0.037 & 0.047 & $-0.063 * * *$ & $-0.062 * * *$ & 0.755 & 0.749 \\
\hline & $(0.374)$ & $(0.469)$ & $(0.444)$ & $(0.346)$ & $(0.000)$ & $(0.000)$ & $(0.512)$ & $(0.519)$ \\
\hline \multirow[t]{2}{*}{ Liquidity } & 0.014 & 0.016 & -0.008 & -0.007 & 0.005 & 0.005 & 0.058 & 0.055 \\
\hline & $(0.347)$ & $(0.285)$ & $(0.364)$ & $(0.432)$ & (0.119) & $(0.102)$ & $(0.210)$ & $(0.256)$ \\
\hline \multirow[t]{2}{*}{ Off. Balance } & 0.000 & 0.000 & -0.000 & -0.000 & $0.000 * * *$ & $0.000 * * *$ & $-0.001 * * *$ & $-0.001 * * *$ \\
\hline & $(0.951)$ & $(0.920)$ & $(0.635)$ & $(0.654)$ & $(0.000)$ & $(0.000)$ & $(0.000)$ & $(0.000)$ \\
\hline \multirow[t]{2}{*}{ Lending } & $-0.064 * * *$ & $-0.060 * * *$ & -0.017 & -0.015 & 0.005 & 0.005 & $0.116^{*}$ & $0.111^{*}$ \\
\hline & $(0.002)$ & (0.004) & $(0.155)$ & $(0.232)$ & $(0.162)$ & $(0.129)$ & $(0.088)$ & $(0.085)$ \\
\hline \multirow[t]{2}{*}{ Foreign share } & $-0.020 * * *$ & $-0.016 * * *$ & $-0.010 * * *$ & $-0.009 * * *$ & $-0.002 *$ & -0.001 & 0.032 & 0.027 \\
\hline & $(0.000)$ & $(0.001)$ & $(0.001)$ & $(0.002)$ & $(0.090)$ & $(0.215)$ & $(0.124)$ & $(0.238)$ \\
\hline \multirow[t]{2}{*}{ Interest rate } & $-0.283^{* * *}$ & $-0.281 * * *$ & $-0.420 * * *$ & $-0.420 * * *$ & $-0.028 *$ & $-0.028^{*}$ & 0.938 & 0.935 \\
\hline & $(0.000)$ & $(0.000)$ & $(0.000)$ & $(0.000)$ & $(0.062)$ & $(0.066)$ & $(0.328)$ & $(0.333)$ \\
\hline \multirow[t]{2}{*}{ Concentration } & $-0.049 * * *$ & $-0.088 * * *$ & -0.003 & $-0.016 * *$ & $-0.013 * * *$ & $-0.020 * * *$ & 0.322 & $0.386^{*}$ \\
\hline & $(0.000)$ & $(0.000)$ & $(0.654)$ & $(0.028)$ & $(0.000)$ & $(0.000)$ & (0.197) & $(0.058)$ \\
\hline \multirow[t]{2}{*}{ Regulation } & $-0.139 * *$ & $-0.384 * * *$ & $0.079 *$ & -0.004 & $0.062 * * *$ & 0.024 & $-2.287 * * *$ & $-1.893 * *$ \\
\hline & $(0.035)$ & $(0.000)$ & $(0.083)$ & $(0.934)$ & $(0.000)$ & $(0.121)$ & $(0.001)$ & $(0.034)$ \\
\hline \multirow[t]{2}{*}{ Constant } & $29.513 * * *$ & $30.120 * * *$ & $10.356 * * *$ & $10.828 * * *$ & $3.309 * * *$ & $3.403 * * *$ & 43.766 & 42.881 \\
\hline & $(0.000)$ & $(0.000)$ & $(0.000)$ & $(0.000)$ & $(0.000)$ & $(0.000)$ & $(0.120)$ & $(0.101)$ \\
\hline Observations & 962 & 962 & 949 & 949 & 994 & 994 & 986 & 986 \\
\hline $\mathrm{R}^{2}$ & 0.316 & 0.315 & 0.369 & 0.372 & 0.210 & 0.207 & 0.019 & 0.019 \\
\hline Mean VIF & 3.598 & 3.609 & 3.598 & 3.609 & 3.598 & 3.609 & 3.598 & 3.609 \\
\hline
\end{tabular}

Note: $\mathrm{Hb} 1=\mathrm{H}$-statistic estimated by OLS in the first stage through specification 1 where interest income is used as the dependent variable in equation (1). $\mathrm{Hb} 3=\mathrm{H}$-statistic estimated using OLS in the first stage through specification 3 where total income is the dependent variable in equation (1). LLR = loan-loss reserves over total loans; LLP = loan-loss provisions over total loans; ROA volatility = the deviation of individual bank's ROA from the sample mean within one period; Z- index = $(\mathrm{ROA}+\mathrm{EAR}) / \mathrm{ROA}$ volatility where ROA = net income over total assets and EAR = equity capital over total assets. The second stage is estimated by applying heteroskedasticity-consistent OLS to equation (4). P-values are in parentheses. Year dummies from 1999 through 2008 are included in the model but not reported. Mean VIF = mean value of the variance inflation factor, used to test for multicollinearity in the regression. As the rule of thumb, if VIF exceeds 10, multicollinearity is severe. * Significant at 0.1 level, ** significant at 0.05 level and $* * *$ significant at 0.01 level. 
Table 7 Competition (measured using the fixed effects H-statistic) and risk

\begin{tabular}{|c|c|c|c|c|c|c|c|c|}
\hline & \multicolumn{2}{|c|}{ LLR } & \multicolumn{2}{|c|}{ LLP } & \multicolumn{2}{|c|}{ ROA Volatility } & \multicolumn{2}{|c|}{$\mathbf{Z}$} \\
\hline & $\mathrm{Hf}^{1}$ & $\mathrm{Hf}^{3}$ & $\mathrm{Hf}^{1}$ & $\mathrm{Hf}^{3}$ & $\mathrm{Hf}^{1}$ & $\mathrm{Hf}^{3}$ & $\mathrm{Hf}^{1}$ & $\mathrm{Hf}^{3}$ \\
\hline Competition & $\begin{array}{l}-21.343 * * * \\
(0.000)\end{array}$ & $\begin{array}{l}-38.956 * * * \\
(0.000)\end{array}$ & $\begin{array}{l}-3.820 * * \\
(0.019)\end{array}$ & $\begin{array}{l}-9.778 * * * \\
(0.000)\end{array}$ & $\begin{array}{l}-3.682 * * * \\
(0.000)\end{array}$ & $\begin{array}{l}-6.381 * * * \\
(0.000)\end{array}$ & $\begin{array}{l}39.046 \\
(0.142)\end{array}$ & $\begin{array}{l}67.015 \\
(0.177)\end{array}$ \\
\hline Size & $\begin{array}{l}-0.199 * * \\
(0.014)\end{array}$ & $\begin{array}{l}-0.133 \\
(0.102)\end{array}$ & $\begin{array}{l}-0.006 \\
(0.890)\end{array}$ & $\begin{array}{l}0.013 \\
(0.774)\end{array}$ & $\begin{array}{l}-0.081 * * * \\
(0.000)\end{array}$ & $\begin{array}{l}-0.071 * * * \\
(0.000)\end{array}$ & $\begin{array}{l}0.946 \\
(0.356)\end{array}$ & $\begin{array}{l}0.837 \\
(0.443)\end{array}$ \\
\hline Liquidity & $\begin{array}{l}0.004 \\
(0.779)\end{array}$ & $\begin{array}{l}0.009 \\
(0.554)\end{array}$ & $\begin{array}{l}-0.012 \\
(0.210)\end{array}$ & $\begin{array}{l}-0.010 \\
(0.263)\end{array}$ & $\begin{array}{l}0.003 \\
(0.296)\end{array}$ & $\begin{array}{l}0.004 \\
(0.192)\end{array}$ & $\begin{array}{l}0.075^{*} \\
(0.059)\end{array}$ & $\begin{array}{l}0.066 \\
(0.113)\end{array}$ \\
\hline Off. Balance & $\begin{array}{l}-0.000 \\
(0.903)\end{array}$ & $\begin{array}{l}-0.000 \\
(0.970)\end{array}$ & $\begin{array}{l}-0.000 \\
(0.592)\end{array}$ & $\begin{array}{l}-0.000 \\
(0.607)\end{array}$ & $\begin{array}{l}0.000 * * * \\
(0.000)\end{array}$ & $\begin{array}{l}0.000 * * * \\
(0.000)\end{array}$ & $\begin{array}{l}-0.001 * * * \\
(0.000)\end{array}$ & $\begin{array}{l}-0.001 * * * \\
(0.000)\end{array}$ \\
\hline Lending & $\begin{array}{l}-0.087 * * * \\
(0.000)\end{array}$ & $\begin{array}{l}-0.075^{* * *} \\
(0.000)\end{array}$ & $\begin{array}{l}-0.025 * * \\
(0.034)\end{array}$ & $\begin{array}{l}-0.022 * \\
(0.065)\end{array}$ & $\begin{array}{l}0.001 \\
(0.678)\end{array}$ & $\begin{array}{l}0.003 \\
(0.355)\end{array}$ & $\begin{array}{l}0.150^{*} \\
(0.067)\end{array}$ & $\begin{array}{l}0.132 * \\
(0.078)\end{array}$ \\
\hline Foreign share & $\begin{array}{l}-0.023 * * * \\
(0.000)\end{array}$ & $\begin{array}{l}-0.023^{* * *} \\
(0.000)\end{array}$ & $\begin{array}{l}-0.011 * * * \\
(0.001)\end{array}$ & $\begin{array}{l}-0.011 * * * \\
(0.000)\end{array}$ & $\begin{array}{l}-0.002 * * \\
(0.027)\end{array}$ & $\begin{array}{l}-0.002 * * \\
(0.032)\end{array}$ & $\begin{array}{l}0.038 * \\
(0.052)\end{array}$ & $\begin{array}{l}0.038^{*} \\
(0.056)\end{array}$ \\
\hline Interest rate & $\begin{array}{l}-0.263^{* * * *} \\
(0.000)\end{array}$ & $\begin{array}{l}-0.276^{* * *} \\
(0.000)\end{array}$ & $\begin{array}{l}-0.413 * * * \\
(0.000)\end{array}$ & $\begin{array}{l}-0.417 * * * \\
(0.000)\end{array}$ & $\begin{array}{l}-0.025 \\
(0.101)\end{array}$ & $\begin{array}{l}-0.027 * \\
(0.073)\end{array}$ & $\begin{array}{l}0.895 \\
(0.331)\end{array}$ & $\begin{array}{l}0.922 \\
(0.327)\end{array}$ \\
\hline Concentration & $\begin{array}{l}0.006 \\
(0.685)\end{array}$ & $\begin{array}{l}-0.005 \\
(0.719)\end{array}$ & $\begin{array}{l}0.006 \\
(0.483)\end{array}$ & $\begin{array}{l}0.007 \\
(0.330)\end{array}$ & $\begin{array}{l}-0.004 \\
(0.159)\end{array}$ & $\begin{array}{l}-0.006 * * \\
(0.013)\end{array}$ & $\begin{array}{l}0.223 \\
(0.468)\end{array}$ & $\begin{array}{l}0.246 \\
(0.412)\end{array}$ \\
\hline Regulation & $\begin{array}{l}0.137 \\
(0.128)\end{array}$ & $\begin{array}{l}0.291 * * * \\
(0.001)\end{array}$ & $\begin{array}{l}0.127 * * \\
(0.042)\end{array}$ & $\begin{array}{l}0.187 * * * \\
(0.003)\end{array}$ & $\begin{array}{l}0.108 * * * \\
(0.000)\end{array}$ & $\begin{array}{l}0.132 * * * \\
(0.000)\end{array}$ & $\begin{array}{l}-2.779 * * * \\
(0.000)\end{array}$ & $\begin{array}{l}-3.022 * * * \\
(0.000)\end{array}$ \\
\hline Constant & $\begin{array}{l}25.328 * * * \\
(0.000)\end{array}$ & $\begin{array}{l}31.255 * * * \\
(0.000)\end{array}$ & $\begin{array}{l}8.714 * * * \\
(0.000)\end{array}$ & $\begin{array}{l}10.416 * * * \\
(0.000)\end{array}$ & $\begin{array}{l}2.714 * * * \\
(0.000)\end{array}$ & $\begin{array}{l}3.636 * * * \\
(0.000)\end{array}$ & $\begin{array}{l}49.911 \\
(0.145)\end{array}$ & $\begin{array}{l}40.257 \\
(0.164)\end{array}$ \\
\hline Observations & 962 & 962 & 949 & 949 & 994 & 994 & 986 & 986 \\
\hline $\mathrm{R}^{2}$ & 0.284 & 0.303 & 0.359 & 0.363 & 0.189 & 0.202 & 0.018 & 0.018 \\
\hline Mean VIF & 3.593 & 3.590 & 3.593 & 3.590 & 3.593 & 3.590 & 3.593 & 3.590 \\
\hline
\end{tabular}

Note: $\mathrm{Hf}^{1}=\mathrm{H}$-statistic estimated by fixed-effects GLS in the first stage through specification 1 where interest income is used as the dependent variable in equation (1). $\mathrm{Hf}^{3}=\mathrm{H}$-statistic estimated using the fixed-effects GLS in the first stage through specification 3 where total income is the dependent variable in equation (1). LLR = loan-loss reserves over total loans; LLP = loan-loss provisions over total loans; ROA volatility $=$ the deviation of individual bank's ROA from the sample mean within one period; Z-index $=(\mathrm{ROA}+\mathrm{EAR}) / \mathrm{ROA}$ volatility where $\mathrm{ROA}=$ net income over total assets and EAR $=$ equity capital over total assets. The second stage is estimated by applying heteroskedasticity-consistent OLS to equation (4). P-values are in parentheses. Year dummies from 1999 through 2008 are included in the model but not reported. Mean VIF = mean value of variance inflation factor, used to test for multicollinearity in the regression. As the rule of thumb, if VIF exceeds 10 multicollinearity is severe. * Significant at 0.1 level, ** significant at 0.05 level and *** significant at 0.01 level. 
Table 8 Competition (measured using the dynamic GMM H-statistic) and risk

\begin{tabular}{|c|c|c|c|c|c|c|c|c|}
\hline & \multicolumn{2}{|c|}{ LLR } & \multicolumn{2}{|c|}{ LLP } & \multicolumn{2}{|c|}{ ROA Volatility } & \multicolumn{2}{|c|}{$\mathbf{Z}$} \\
\hline & $\mathrm{Hd}^{1}$ & $\mathrm{Hd}^{3}$ & $\mathrm{Hd}^{1}$ & $\mathrm{Hd}^{3}$ & $\mathrm{Hd}^{1}$ & $\mathrm{Hd}^{3}$ & $\mathrm{Hd}^{1}$ & $\mathrm{Hd}^{3}$ \\
\hline Competition & $\begin{array}{l}-26.077 * * * \\
(0.000)\end{array}$ & $\begin{array}{l}-10.484 * * * \\
(0.000)\end{array}$ & $\begin{array}{l}-8.076 * * * \\
(0.000)\end{array}$ & $\begin{array}{l}-3.550 * * * \\
(0.000)\end{array}$ & $\begin{array}{l}-4.089 * * * \\
(0.000)\end{array}$ & $\begin{array}{l}-1.621 * * * \\
(0.000)\end{array}$ & $\begin{array}{l}42.557 \\
(0.252)\end{array}$ & $\begin{array}{l}16.764 \\
(0.297)\end{array}$ \\
\hline Size & $\begin{array}{l}-0.068 \\
(0.414)\end{array}$ & $\begin{array}{l}-0.061 \\
(0.467)\end{array}$ & $\begin{array}{l}0.040 \\
(0.410)\end{array}$ & $\begin{array}{l}0.048 \\
(0.343)\end{array}$ & $\begin{array}{l}-0.063 * * * \\
(0.000)\end{array}$ & $\begin{array}{l}-0.063 * * * \\
(0.000)\end{array}$ & $\begin{array}{l}0.749 \\
(0.517)\end{array}$ & $\begin{array}{l}0.751 \\
(0.518)\end{array}$ \\
\hline Liquidity & $\begin{array}{l}0.014 \\
(0.325)\end{array}$ & $\begin{array}{l}0.016 \\
(0.284)\end{array}$ & $\begin{array}{l}-0.008 \\
(0.382)\end{array}$ & $\begin{array}{l}-0.007 \\
(0.436)\end{array}$ & $\begin{array}{l}0.005 \\
(0.112)\end{array}$ & $\begin{array}{l}0.005 \\
(0.101)\end{array}$ & $\begin{array}{l}0.057 \\
(0.225)\end{array}$ & $\begin{array}{l}0.055 \\
(0.257)\end{array}$ \\
\hline Off. Balance & $\begin{array}{l}0.000 \\
(0.941)\end{array}$ & $\begin{array}{l}0.000 \\
(0.919)\end{array}$ & $\begin{array}{l}-0.000 \\
(0.640)\end{array}$ & $\begin{array}{l}-0.000 \\
(0.656)\end{array}$ & $\begin{array}{l}0.000 * * * \\
(0.000)\end{array}$ & $\begin{array}{l}0.000 * * * \\
(0.000)\end{array}$ & $\begin{array}{l}-0.001 * * * \\
(0.000)\end{array}$ & $\begin{array}{l}-0.001 * * * \\
(0.000)\end{array}$ \\
\hline Lending & $\begin{array}{l}-0.062 * * * \\
(0.003)\end{array}$ & $\begin{array}{l}-0.060 * * * \\
(0.004)\end{array}$ & $\begin{array}{l}-0.017 \\
(0.174)\end{array}$ & $\begin{array}{l}-0.015 \\
(0.236)\end{array}$ & $\begin{array}{l}0.005 \\
(0.148)\end{array}$ & $\begin{array}{l}0.005 \\
(0.129)\end{array}$ & $\begin{array}{l}0.114 * \\
(0.088)\end{array}$ & $\begin{array}{l}0.111 * \\
(0.085)\end{array}$ \\
\hline Foreign share & $\begin{array}{l}-0.019 * * * \\
(0.000)\end{array}$ & $\begin{array}{l}-0.016 * * * \\
(0.001)\end{array}$ & $\begin{array}{l}-0.010 * * * \\
(0.001)\end{array}$ & $\begin{array}{l}-0.009 * * * \\
(0.002)\end{array}$ & $\begin{array}{l}-0.002 \\
(0.111)\end{array}$ & $\begin{array}{l}-0.001 \\
(0.228)\end{array}$ & $\begin{array}{l}0.031 \\
(0.146)\end{array}$ & $\begin{array}{l}0.027 \\
(0.249)\end{array}$ \\
\hline Interest rate & $\begin{array}{l}-0.283 * * * \\
(0.000)\end{array}$ & $\begin{array}{l}-0.281 * * * \\
(0.000)\end{array}$ & $\begin{array}{l}-0.420 * * * \\
(0.000)\end{array}$ & $\begin{array}{l}-0.420 * * * \\
(0.000)\end{array}$ & $\begin{array}{l}-0.028 * \\
(0.062)\end{array}$ & $\begin{array}{l}-0.028 * \\
(0.067)\end{array}$ & $\begin{array}{l}0.938 \\
(0.329)\end{array}$ & $\begin{array}{l}0.934 \\
(0.333)\end{array}$ \\
\hline Concentration & $\begin{array}{l}-0.058 * * * \\
(0.000)\end{array}$ & $\begin{array}{l}-0.091 * * * \\
(0.000)\end{array}$ & $\begin{array}{l}-0.006 \\
(0.401)\end{array}$ & $\begin{array}{l}-0.017 * * \\
(0.020)\end{array}$ & $\begin{array}{l}-0.015 * * * \\
(0.000)\end{array}$ & $\begin{array}{l}-0.020 * * * \\
(0.000)\end{array}$ & $\begin{array}{l}0.337 \\
(0.158)\end{array}$ & $\begin{array}{l}0.390 * \\
(0.051)\end{array}$ \\
\hline Regulation & $\begin{array}{l}-0.284 * * * \\
(0.000)\end{array}$ & $\begin{array}{l}-0.402 * * * \\
(0.000)\end{array}$ & $\begin{array}{l}0.034 \\
(0.446)\end{array}$ & $\begin{array}{l}-0.011 \\
(0.822)\end{array}$ & $\begin{array}{l}0.039 * * * \\
(0.006)\end{array}$ & $\begin{array}{l}0.021 \\
(0.178)\end{array}$ & $\begin{array}{l}-2.051 * * \\
(0.011)\end{array}$ & $\begin{array}{l}-1.864 * * \\
(0.041)\end{array}$ \\
\hline Constant & $\begin{array}{l}39.466 * * * \\
(0.000)\end{array}$ & $\begin{array}{l}31.367 * * * \\
(0.000)\end{array}$ & $\begin{array}{l}13.499 * * * \\
(0.000)\end{array}$ & $\begin{array}{l}11.274 * * * \\
(0.000)\end{array}$ & $\begin{array}{l}4.868 * * * \\
(0.000)\end{array}$ & $\begin{array}{l}3.596 * * * \\
(0.000)\end{array}$ & $\begin{array}{l}27.560 \\
(0.185)\end{array}$ & $\begin{array}{l}40.890 * \\
(0.098)\end{array}$ \\
\hline Observations & 962 & 962 & 949 & 949 & 994 & 994 & 986 & 986 \\
\hline $\mathrm{R}^{2}$ & 0.317 & 0.314 & 0.370 & 0.372 & 0.210 & 0.207 & 0.019 & 0.019 \\
\hline Mean VIF & 3.600 & 3.610 & 3.600 & 3.610 & 3.600 & 3.610 & 3.600 & 3.610 \\
\hline
\end{tabular}

Note: $\mathrm{Hd} 1=\mathrm{H}$-statistic estimated using the dynamic panel estimator in the first stage through specification 1 where interest income is the dependent variable in equation (3). $\mathrm{Hd} 3=\mathrm{H}$-statistic estimated using the dynamic panel estimator in the first stage through specification 3 where total income is as the dependent variable in equation (3). LLR $=$ loan-loss reserves over total loans; LLP = loan-loss provisions over total loans; ROA volatility $=$ the deviation of individual bank's ROA from the sample mean within one period; Z-index $=(\mathrm{ROA}+\mathrm{EAR}) / \mathrm{ROA}$ volatility where $\mathrm{ROA}=$ net income over total assets and $\mathrm{EAR}$ = equity capital over total assets. The second stage is estimated by applying heteroskedasticity-consistent OLS to equation (4). $\mathrm{P}$-values are in parentheses. Year dummies from 1999 through 2008 are included in the model but not reported. Mean VIF = mean value of variance inflation factor, used to test for multicollinearity in the regression. As the rule of thumb, if VIF exceeds 10 multicollinearity is severe. * Significant at 0.1 level, ** significant at 0.05 level and *** significant at 0.01 level. 
Appendix I. Summary of H-statistic estimates and equilibrium test outcomes

\begin{tabular}{|c|c|c|c|c|}
\hline Authors & Sample period & Country & Results & Equilibrium \\
\hline Shaffer (1982) & 1979 & US (New York) & Monopolistic competition & Yes \\
\hline Nathan and Neave (1989) & 1982-1984 & Canada & Monopolistic competition & Not estimated \\
\hline Molyneux et al. (1994) & 1986-1989 & $\begin{array}{l}\text { France, Germany, Italy, } \\
\text { Spain and UK }\end{array}$ & Monopolistic competition, except Italy (monopoly) & $\begin{array}{l}\text { No (France: 1987, Italy: 1986, } \\
\text { 1987, Spain: 1987, } 1989 \text { and UK: } \\
\text { 1987, 1989) }\end{array}$ \\
\hline Molyneux et al. (1996) & 1986 and 1988 & Japan & Monopolistic competition in 1988; monopoly in 1986 & Yes \\
\hline Hondroyiannis et al. (1999) & 1993-1995 & Greek & Monopolistic competition & No $(1993,1994)$ \\
\hline De Bandt and Davis (2000) & 1992-1996 & $\begin{array}{l}\text { France, Germany, Italy, and } \\
\text { US }\end{array}$ & $\begin{array}{l}\text { Monopolistic competition } \\
\text { Monopoly for small banks in France and Germany }\end{array}$ & No (for large banks in Italy) \\
\hline Bikker and Haaf (2002) & 1988-1998 (varying) & 23 industrialized nations & Monopolistic competition & Yes, not reported (p. 2200) \\
\hline Hempell (2002) & 1993-1998 & Germany & Monopolistic competition & Not estimated \\
\hline Claessens and Laeven (2004) & 1994-2001 & 50 countries & $\begin{array}{l}\text { Monopolistic competition, competition in } \\
\text { more advanced nations tend to be less intense }\end{array}$ & Yes, most countries (not reported) \\
\hline Coccorese (2004) & 1997-1999 & Italy & Monopolistic competition & Yes \\
\hline Gelos and Roldos (2004) & 1994-1999 (varying) & 8 emerging countries & Monopolistic competition & No (3 countries) \\
\hline Shaffer (2004) & March 1984-June 1994 & US ( 4 banks, quarterly) & Monopolistic competition & No (10 cases) \\
\hline Buchs and Mathisen (2005) & $1998-2003$ & Ghana & Monopolistic competition & Yes \\
\hline Al-Muharrami et al. (2006) & 1993-2002 & 6 Arab GCC countries & Monopolistic competition & No (for pooled country estimation) \\
\hline Casu and Girardone (2006) & $1997-2003$ & 15 European countries & Monopolistic competition except 2 countries & Yes, most countries, (p. 461) \\
\hline Laeven (2006) & 1994-2004 (varying) & 7 East Asian countries & Monopolistic competition & Not estimated \\
\hline \multicolumn{5}{|l|}{ Staikouras and } \\
\hline Koutsomanoli-Fillipaki (2006) & 1998-2002 & 25 European countries & Monopolistic competition & No (for small banks) \\
\hline Yuan (2006) & $1996-2000$ & China & Monopolistic competition & Yes \\
\hline Matthews et al. (2007) & 1980-2004 & UK & Monopolistic competition & No (full sample period) \\
\hline
\end{tabular}




\begin{tabular}{|c|c|c|c|c|}
\hline Yeyati and Micco (2007) & 1993-2002 (varying) & 8 Latin American countries & Monopolistic competition & Not estimated \\
\hline Yildirim and Philippatos (2007) & $1993-2000$ & 13 Latin American countries & Monopolistic competition & No (4 countries $)$ \\
\hline Coccorese (2009) & $1988-2005$ & Italy & Monopolistic competition & No \\
\hline Delis (2009) & 1999-2006 & $\begin{array}{l}22 \text { countries in Central and } \\
\text { Eastern Europe }\end{array}$ & Monopolistic competition in most countries & Yes (Except Bosnia and Estonia) \\
\hline Park (2009) & $1992-2004$ & Korea & Monopolistic competition & $\begin{array}{l}\text { Yes (1992-1996 and 2001-2004) } \\
\text { No (1997-2000) }\end{array}$ \\
\hline Turk-Ariss (2009) & $2000-2006$ & $\begin{array}{l}12 \text { countries in the Middle } \\
\text { East and North Africa }\end{array}$ & Monopolistic competition in most countries & Yes \\
\hline
\end{tabular}

Note: Compiled by the authors 